Revue d'histoire de l'enfance « irrégulière »

Le Temps de l'histoire

15 | 2013

Enfances déplacées. (II) en temps de guerre

\title{
The "Other" Child Transports: World War I and the Temporary Displacement of Needy Children from Central Europe
}

Les déplacements temporaires d'enfants déshérités en Europe centrale pendant la première guerre mondiale.

\section{Friederike Kind-Kovács}

\section{OpenEdition}

\section{Journals}

Electronic version

URL: http://journals.openedition.org/rhei/3474

DOI: 10.4000/rhei.3474

ISSN: $1777-540 \mathrm{X}$

Publisher

Presses universitaires de Rennes

Printed version

Date of publication: 30 October 2013

Number of pages: 75-109

ISBN: 978-2-7535-2896-3

ISSN: 1287-2431

\section{Electronic reference}

Friederike Kind-Kovács, «The "Other" Child Transports: World War I and the Temporary Displacement of Needy Children from Central Europe », Revue d'histoire de l'enfance « irrégulière » [Online], 15 | 2013, Online since 30 October 2015, connection on 30 April 2019. URL : http://journals.openedition.org/ rhei/3474 ; DOl : 10.4000/rhei.3474

This text was automatically generated on 30 April 2019.

(C) PUR 


\title{
The "Other" Child Transports: World War I and the Temporary Displacement of Needy Children from Central Europe
}

\author{
Les déplacements temporaires d'enfants déshérités en Europe centrale pendant \\ la première guerre mondiale.
}

Friederike Kind-Kovács

“Hungarian children in Holland," Mühlbeck Károly

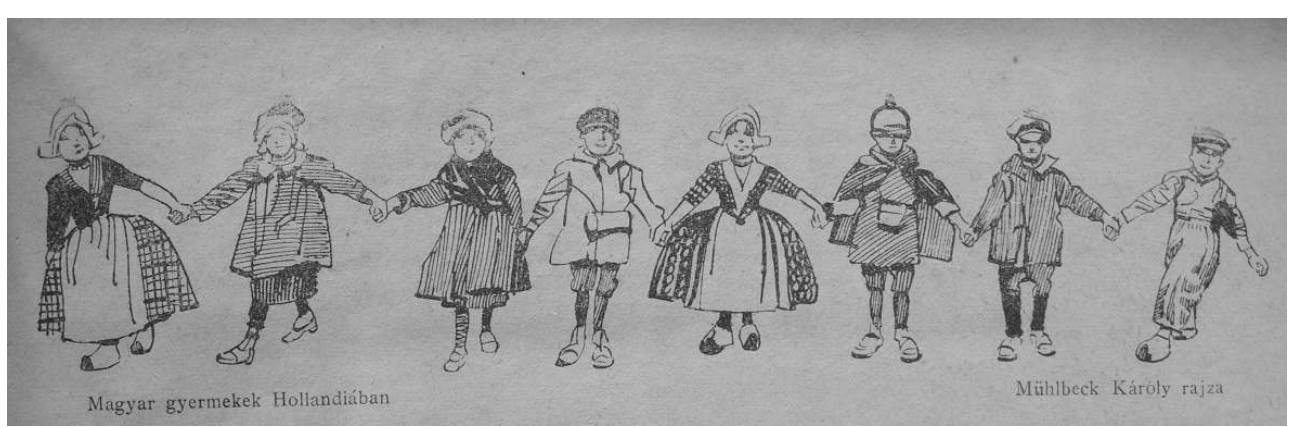

"Magyar gyermekek Hollandiaban," in Új idök 192026 évfolyam, p. 37.

While during both world wars, fathers often returned as invalids and mothers became breadwinners for their families, children suffered most intensely from the silent side- and after-effects of the wars, mainly from neglect, contagious diseases, and starvation. During and after the First World War, their disproportionate suffering no longer fell into complete oblivion. Instead, it yielded new philanthropic visions and policies of child relief that hoped to counter children's extensive pauperization and perishing that had resulted from the war. This article examines the impact of WWI and the dissolution of the AustroHungarian Empire on children in the Austro-Hungarian monarchy and its successor states. It focuses particularly on the practice of children's temporary displacement as one 
of the most documented relief activities during the last years of the war and the early post-war period. While during the war, children's displacement was thought of as an extended summer vacation, the post-war child transports operated-geographically and in time-on a different scale. Taking both movements into account, this article aims at tracing the transformation from the late imperial to the transnational humanitarian child transports, paying special attention to the role of visual imagery to justify, illustrate, and document the children's geographic displacement.

2 However, in the case of Hungary neither children's poverty nor their relief was anything new. Just the intensity of both gained a new dimension in the final years of WWI and its disruptive aftermath. Already in the $19^{\text {th }}$ century religious as well as charity organizations throughout Europe had been implementing philanthropic practices of child relief to counter the increased child poverty and mortality that had gone hand in hand with processes of modernization and industrialization. ${ }^{1}$ The call for a better awareness of children's concerns comprised their protection from physical and mental abuse, from neglect, their right to health protection and their exemption from labor. Many private and religious charities also aimed to better meet children's care needs, helping to place orphaned or abandoned children in institutional care. Individual social workers or philanthropists like the English philanthropist Emily Hobhouse, who exposed the disastrous conditions of children in concentration camps during the Anglo-Boer War (1899-1902) ${ }^{2}$, or Dr. Barnardo, who created homes for poor children in Britain, promoted the concerns of children. While $19^{\text {th }}$ century child protection mainly targeted the children of the poor out of religious motivations, the turn of the century saw a shift towards the governmental intervention in the field of child protection and welfare. ${ }^{3}$ In the case of Hungary, which is at the center of this article, public child protection and welfare became institutionalized in the framework of new social welfare laws in 1901/1903. Public child protection was not only financed but also organized through the state, with the aim of systematically decreasing child mortality. ${ }^{4}$ The Hungarian National Child Protection League (Országos Gyermekvédö Liga), founded in 1906, served as a private charity to supplement the public child protection. In 1915 the Stefánia Association (Országos Stefánia Szövetség) was founded, providing emergency infant and mother care to take up the fight against the country's high infant mortality.

3 While the first decade of the $20^{\text {th }}$ century saw a professionalization and institutionalization of child welfare on the Hungarian territory, the Great War affected both children's lives as well as the situation of the child saving movement in manifold ways. The war as an international humanitarian crisis caused an unknown extent of civilian suffering, calling for broad wartime and postwar humanitarian relief on an international basis. ${ }^{5}$ The response was the establishment of a series of international humanitarian relief organizations. The philanthropist Eglantyne Jebb and her sister Dorothy Buxton founded in 1919 one of the most important non-governmental child protection organizations, the well-known British Save the Children Fund (SCF). By means of this philanthropic organization, they aimed to alleviate the suffering of children from wars and other disasters. ${ }^{6}$ What was intrinsically perverse about the system of humanitarian relief was and still is the fact that relief itself is living off war and disasters. Organizations such as the Red Cross "actually needed the war which had become its raison d'être." Focusing on the large parts of the involved but unarmed civilian populations, which had suffered from war atrocities, international humanitarian organizations kept "advocating neutrality and peace while war [...] was raging" and whilst the "mentality of 
war" occupied the minds of its people. ${ }^{7}$ As the First World War targeted the civilian population and affected children's lives to an unknown extent, it equally "inspired the first international effort to 'reclaim' and rehabilitate children uprooted by wartime displacement [...] or ethnic cleansing ${ }^{8, "}$ poverty and neglect. The massive presence of starving, orphaned or sick children in the public lives of the major cities of Hungary called for their immediate relief. ${ }^{9}$ While during the war imperial and national child welfare was still active, during the initial post-war years, national child relief organizations such as the Stefánia Association and the Hungarian National Child Protection League had to rely heavily on international support to provide the urgently needed child relief.

The First World War marked not only "the birth of the modern refugee ${ }^{10}$," but also a new stage of children's displacement and their resulting extensive suffering. As in the case of Hungary, the end of the war also represented, on October 31, 1918, the end of the AustroHungarian Empire as a geographic territory. Post-war Hungarian society was confronted with large territorial and populational changes. The making of the modern nation-states and the ideal of national self-determination "implied not only the naming of certain people as enemies of the nation," but it equally demanded the expulsion of ethnic minorities from the new-style nation states. ${ }^{11}$ As a result, a mass migration of about 350.000 refugees $^{12}$ from the former Hungarian territories took place, which produced a large number of "lost", meaning unsupervised, orphaned or neglected children. The Hungarian child mortality rate of about 20 percent was amongst the highest in Europe. ${ }^{13}$ Throughout Central and Eastern Europe, the immediate post-war period represented an extremely difficult situation, "with exorbitant infant mortality and [...] masses of unsupervised children. ${ }^{14}$ " The naval blockade of the Allied powers played much into this, as the import of foodstuffs was entirely cut off from the Central Powers since 1914.

In a reaction to the intensifying child poverty in the countries of the Central Powers, a number of international political and humanitarian organizations turned the destiny of children, as the unwanted victims of war, into a public topic. Among them were the Save the Children Fund (SCF), the American Red Cross (ARC), the International Committee of the Red Cross (ICRC), and Hoover's American Relief Administration (ARA). All of these initiatives played a central role in providing material aid to the impoverished Central European countries. But how could any envisioned relief-after so many years of fierce battle and ongoing mutual atrocities-encompass the enemy population or the enemy's children? How could humanitarian child relief for children whose parents had been fighting in the war on the wrong side become again possible? Or what about children who had been the product of violent atrocities such as rape in periods of military occupation? As "punishment and delegitimization of the enemy's war" stood in the foreground of the war- and postwar rhetoric, the war's "defenseless victims were quickly forgotten," which initially turned any relief of enemy children unimaginable..$^{15}$ For instance in the case of France during WWI many women, who had been raped by the German occupying forces, right away decided to abort the children of the "barbares.' The "German blood" was believed to prevent the enemy children from ever being able to appropriately assimilate to the French nation, which therefore entirely "justified and even legitimized abortion or infanticide" as appropriate solutions. ${ }^{16}$ The violent intrusion into the body through enemy aggression turned the "innocent" offspring into undesirable and unwanted beings, that weren't considered worth living. ${ }^{17}$ WWI left Europe deeply divided between the 
Allied and the Central Powers not just among its soldiers and armies, but also among its civil populations, that hoped for revenge for their individual suffering.

6 As the militarization of the civil population had also included children as a valuable target group, it also spoiled children's apparently complete innocence. For this reason, either "children of the enemy" outside the Allied Powers' own national borders were supposed to be fed or relieved. Therefore, the British and American public initially rejected the idea of politicians like Herbert Hoover (ARA) or philanthropists like Eglantyne Jebb (SCF) of providing aid to children of former enemy states. Feeding for instance Russian children, who were starving during and after the Russian Famine of 1921, was believed to further fuel Bolshevism. ${ }^{18}$ Still, persisting individuals like Hoover and Jebb managed to advocate children and childhood as a "zone of peace ${ }^{19}$," in which only the humanitarian cause counted and opposition perished. The fact that children did represent a "large part of the noncombattants ${ }^{20}$ " convinced the hesitant publics to overcome their prejudices and doubts. Furthering this concept of children and childhood, they ignored the friend-enemy scheme, which had been nourished by the violent conflict, and provided the needed relief even to the enemy's children. For this reason, humanitarian idea of child relief did not stop before the enemy's children, but instead worked on relieving the suffering of children on both sides of the violent conflict. In the case of Hungary, international humanitarian aid flooded the country from 1919 onwards, but before then national and imperial relief could not rely on outside help.

7 The newly emerging public and international awareness of the suffering of the war victims resulted in an increased visual representation of children's suffering in public discourse. In this sense, World War I and the dissolution of the Austro-Hungarian Empire not only triggered displacement, starvation, illnesses, neglect, and housing problems. The war and its dire consequences equally resulted in an increased publicity for children's health and physical concerns. Contemporary media outlets played an important role in the philanthropic effort to draw attention to children's needs. Already early philanthropists like Hobhouse or Barnardo used photography of children (not always only in a truthful way) to create publicity and mobilize empathy for children's poverty or suffering. ${ }^{21}$ In the immediate post-WWI period the image of the starving child figures in major visual and printed media of the time as one of the most frequently used images. In her much acclaimed work Regarding the Pain of Others, Susan Sontag introduces the immense human fascination with the iconography of suffering. She wonders why images of severely harmed human bodies, mutilated, slaughtered, tortured, or killed, have become an essential component of the representation of war and war atrocities. This "disaster imagery 22," embracing the relations between catastrophe and visual media, plays heavily on feelings of empathy, compassion, and pity with the aim to trigger immediate activism. The imagery of pitiful suffering was born from the belief in the power of "spectatorial sympathy" and the strange "fascination with pain" to appeal to the sensitivity and empathy of the spectator. ${ }^{23}$ This new humanitarian visual and verbal rhetoric countered the politically propagated claim of the undeserving enemy or villain, who was morally not worthy any sympathy or support. ${ }^{24}$ Yet, the imagery of war could equally be used to provide an opportunity "for regarding-at a distance, through the medium of photography-other people's pain", including casualties, mine injuries, or the visibly physical suffering that results from poverty, starvation, and hunger. ${ }^{25}$ To regard the pain of children from afar affected only in very subtle the way of its distant viewer. 
The visual world of disasters, emergencies, and wars, however, does not only depict human suffering, but it also equally embraces the pictorial representation of emergency relief and humanitarianism. The mobilization of pity, compassion and empathy was central in raising awareness for children's suffering, which was expected to lead to financial support for relief measures. ${ }^{26}$ Hugo Slim identified the ambivalence involved in humanitarian relief in periods of war and other human disasters:

"If humanitarian values are given too much consideration in situations of war or political violence, political and military leaders fear that they might undermine their followers' will to fight, or provide succour to their enemy. Nevertheless, it is part of the paradox of human nature that humanitarian values can be present in war. ${ }^{27 "}$

9 Since the late nineteenth century, and in particular following World War I, war and relief have gone hand in hand, employing similar and often identical images of suffering. As James Vernon has argued, throughout modern history the hungry only had become figures of humanitarian concern "when novel forms of news reporting connected people emotionally with the suffering of the hungry." In the early $20^{\text {th }}$ century physical signs of starvation no longer represented social stigmata, and the hungry were no longer perceived as "lazy, morally inadequate human beings. ${ }^{28 "}$ "The visual depiction of the needy and the suffering gained momentum when the traumatic impact of World War I severely affected the physical integrity of the societies and populations involved. The extreme violence of Europe's First World War resulted in a new perspective on the mutilated, starved, and suffering human body. As World War I represented (WWI) as the first total war and had mobilized a "culture of violence", it left its populations "unable to see how deeply and irreversibly affected they were by its brutalization..$^{29}$ " The imagery of suffering became radicalized insofar as it was driven by hatred for the enemy. As an easy means of political and national self-victimization in the postwar period, children were considered ideal to serve as the iconographic bearers of suffering, and their physical vulnerability was given immense attention. As " $[\mathrm{t}]$ he child was the quintessential represented political subject, spoken for but not speaking ${ }^{30, " ~ c h i l d r e n ' s ~ i m a g e r y ~ s e r v e d ~}$ political as well as humanitarian aims. From its very beginning humanitarian organizations used child images to create and to publicize its humanitarian identity. Child imagery was always useful in connoting humanitarian organizations with widely appreciated ideas of childhood. In the period after WWI the increasing visual representation of children allowed to appeal for the relief of children's suffering across Europe. Images of children's suffering conveyed a moral force upon the spectator, engaging him/her with the victims of the war and engaging financially in their urgent relief.

In the history of child relief one such relief activity and possibly the most drastic relief campaign was the short- and medium-term relocation or displacement of impoverished children, which was much documented by the contemporary media. One of the bestknown forms of this child saving practice started as a social experiment in the mid-19 $9^{\text {th }}$ century USA. By means of the Orphan Train Movement, the US-Children's Aid Society sent between 150.000 to 200.000 abandoned, orphaned or homeless children from large cities to foster parents in smaller cities and villages to to regain control over the massive immigration to North America. ${ }^{31}$ In reaction to the Irish Potato Famine in 1845-1852 children were also sent abroad and even adopted by families in Canada and Australia. ${ }^{32}$ In the framework of the Armenian Genocide (1915-1923), the Ottoman Empire forcefully abducted those Armenian children to Russia and Greece, which had not been killed right 
away. ${ }^{33}$ In reaction to the Russian Famine of 1921, 2000 Soviet children from faminestricken provinces were sent abroad. Although many offers had come from various Western 'bourgeois' countries, Soviet Russia only accepted the offer to send her starving children to Czechoslovakia. ${ }^{34}$ As a means of protection also during the Spanish Civil War (1936-39) orphaned and abandoned children were taken to the Soviet Union, Mexico, France and England. ${ }^{35}$ Throughout the Nazi-period Jewish children were evacuated to Britain. Throughout WWII, in Europe, children were evacuated from urban areas, among which the Kinderlandverschickungen in Germany and the British evacuation plans are well known. During the Greek Civil War (1946-1949) children were transported to Central and Eastern Europe.

During and after WWI, These transports were perceived as a necessary means to guarantee the bodily well-being of the impoverished and starving children. The history of the child transports or other relief measures during and after the First World War cannot be written without taking into account its visual propaganda. Photographic footage, drawings, posters, paintings, postcards, and other visual material accompany almost all contemporary written sources of child relief. They document the children's suffering before the relief activities, the implementation of the activities, and the children's transformation by means of the relief. Eglantyne Jebb, the founder of SCF, even argued that it was photographic imagery that had initiated her own activism, and that it had greatly helped to create publicity for the cause of the children. ${ }^{36}$ Already during the early Balkan wars (1912-1913) Eglantyne traveled to the conflict zone to deliver money to the Macedonian Relief Fund. ${ }^{37}$ Witnessing there the suffering of Muslim Albanian refugee children, Jebb' returned to Britain with the plan to raise funds for the relief of the refugee children. ${ }^{38}$ Short after, WWI started and the problem of children's neglect, starvation and illnesses in the Eastern parts of Europe radically intensified. Jebb remembered her sister coming back from Central Europe with some of the first images of suffering children, which led her to start publicizing their misery on the streets of London, simply by sharing the photographs. Initially Jebb's and Buxton's activities for the support of the enemy's children generated opposition and was even met with stirring hostility by parts of the British society. A report about children's life in Budapest from 1920 links photography with its claim to impart 'the' truth. On an inspection tour through Budapest's poor neighborhoods, the members of the Entente Missions to Budapest have "inspected the dwellings of poverty shown in the preceding photographs and have convinced themselves of the truthfulness of the particulars stated." Based on this experience, they felt committed to "limit [...] [them]selves to reporting facts of the truthfulness, which may be verified by means of names and addresses or other adequate evidence. ${ }^{39}$ " Documenting the 'real existing' misery verbally and visually played a vital role for the reinvention of child relief during WWI and its aftermath.

Whereas in the beginning of the war, the mobilization of children at the home front was the central element of visual propaganda, during its final years the degeneration of children's health became a central topic. Famine, severe malnutrition, epidemic, disease, and physical neglect shaped the lives of children. On February 25, 1918, the AustroHungarian Ministry of Social Welfare in Vienna reported about the planned "Accommodation of Austrian Children in Hungary" that the "industries in lower Austria, which have reached their full development throughout the war, have [...] intensified the problem of food supply," and that "mothers, whose children show all signs of severe malnutrition, constantly visit [...] [their] counseling services. ${ }^{40 "}$ The war and its industries 
as well as the blockade of the Central Powers from 1914 until 1919 (even beyond the armistice) restricted the supply of foodstuffs through imports. ${ }^{41}$ This means of economic warfare was seen as responsible for children's severe starvation and overall deprivation. ${ }^{42}$ Eglantyne Jebb and her sister Dorothy Buxton campaigned against the Allies' starvation policy and distributed in early 1919 leaflets "A Starving Baby and Our Blockade Has Caused This" in Trafalgar Square..$^{43}$ Already during the war Herbert Hoover started his Commission for Relief in Belgium (CRB) to relieve the suffering of the civil population in German-occupied Belgium, which faced a serious food crisis. ${ }^{44}$ Although in AustriaHungary the Hunger crisis was even more severe, its reason was not merely the hunger blockade. ${ }^{45}$ Its own radically diminished agricultural production and its interrupted intraimperial transport of foodstuffs led to famine. ${ }^{46}$ International humanitarian relief was initiated only much later. The destiny of urban children in Budapest was seen as particularly severe, because the major cities had suffered more from the war than Hungary's rural regions. The increasing industrialization and urbanization had already generated the problem of child neglect and abandonment from the late nineteenth century onwards, but children's severe malnutrition culminated in the immediate postwar years. ${ }^{47}$ These disaster stories and their visual representations relied either on personal stories of suffering children and their families, or on an abstract, iconic child image to generalize the suffering of the child. The imagery of suffering, used by humanitarian organizations, was often supplemented with a depiction of its immediate alleviation, uncovering a dichotomist visual language: "The practice of representing atrocious suffering as something to be deplored, and, if possible, stopped, enters the history of images with a specific subject: the sufferings endured by a civilian population at the hands of a victorious army on the rampage. ${ }^{48}$ " In the same way as these images were much needed to raise funds for child relief activities, textual propaganda was central in stressing the dependence between the lucky recipient and the humanitarian beneficiary.

In a letter to the Ministry of Social Welfare, the first of its sort, which Kaiser Karl had founded in 1917, the Austro-Hungarian People's Nutrition Office thanked Karl I for his initiative. Any help provided to the city and its children "represented an extraordinarily valuable support to our metropolis which has suffered more than any other of the capitals of the belligerent States. Not only these benefitting by the Committee's humanitarian activity, but every citizen of this town will always remember these noble efforts towards alleviating human suffering. ${ }^{49}$ "The imperial Kaiser Karl Wohfahrtswerk, which was named after the last Austrian Emperor Karl I and located in Vienna, pushed for child relief during the last years of the war, even if it provided only temporary help. ${ }^{50} \mathrm{On}$ July 1, 1918, the official commissioner of the Kaiser Karl Wohlfahrtswerk clarified for which children the relief was intended:

“This children's action stands under the highest patronage and is able to care for the poorest children of the population [...] [...] [T] hese poor children, among which mostly war orphans can be found, should receive weekly the same food rations as our needy children. [...] I must emphasize that we plan to only provide for the poorest children of the population. Therefore special care shall be taken with [the] selection process. ${ }^{51 "}$

Urban children were the main target group, as the cities had suffered most intensely from the war and its industries. Not only through the war, but already since the late nineteenth century, the "city" had turned into the embodiment of overpopulation, lack of food, missing hygiene and sickening industrialization. The war had intensified many of 
these urban problems, but children most severely suffered from the lack of food. Before a child would, however, receive child relief, it had to pass a medical examination. Their overall physical condition as well as their weight decided which children were to receive child relief in the cities and villages, and which children were to be sent to the countryside or the seashore. Children, who were not too ill, but thin enough to pass the examination for necessity, were ideally suited to participate in the campaign.

"Infront of the recruiting commission"

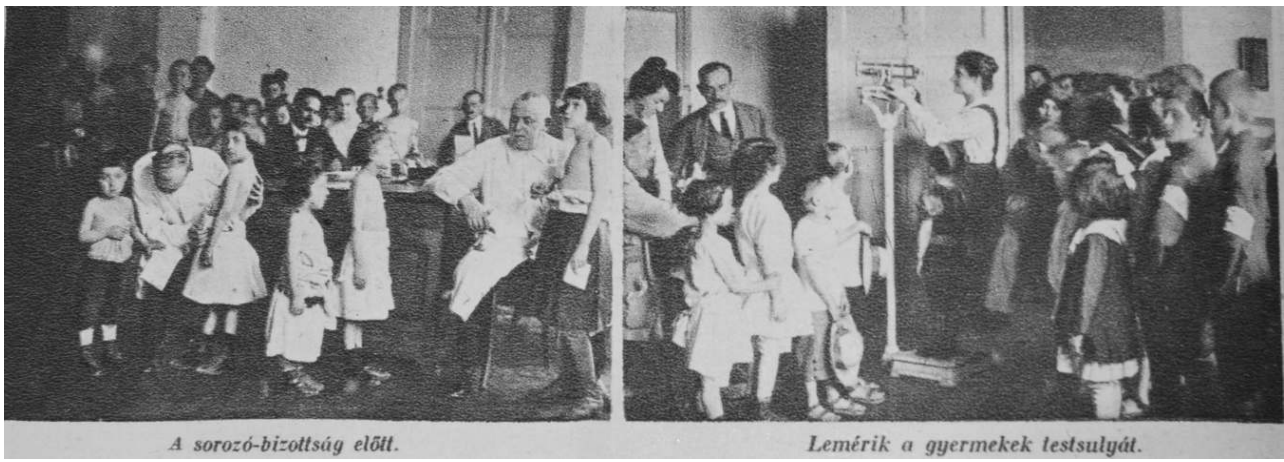

"Infront of the recruiting commission"; "Measuring the body weight," Budapest 1918.52

Apart from feeding hungry children, providing medical care, and placing orphaned children in foster families or in state asylums, the Wohlfahrtswerk initiated a large-scale summer action. During the war's last two summers-the final years of the AustroHungarian monarchy-needy urban children from the Empire were sent to rural or coastal areas to recover from the strains of war. This type of child migration allows us to see the imperial response to the problem of emerging child poverty. In 1917, the "Kinder aufs Land" and the "Kind zu Gast" campaigns initiated the transport of thousands of urban children to the countryside. The action was devoted to the mutual exchange of children across the empire. ${ }^{53}$

Before the collapse of the empire, the Hungarian countryside represented an attractive destination for children from other crown lands. Children in the age of 6 to 14 could apply for a stay in the countryside for several weeks. ${ }^{54}$ Children from the Germanspeaking parts of Bohemia as well as children from lower Austria were sent to smaller holiday resorts or towns like Gyula, Békés, or Grosswardein. ${ }^{55}$ In a personal report, Hugo Wagner, an accompanying person to a transport from Reichenberg [today Liberec] to Gyula, remembers the children's reaction to the-comparably-abundant food supply in rural Hungary. He recounts the story of a small boy who was lying sick in his foster parents' "lonely Tanya," a typical Hungarian farmer's house, "which in this case was uncomfortable and barely furnished". The boy appeared miserable as he had a fever and "did not understand anyone," but he "stubbornly refused to leave" this unfriendly place, as "he had been told that he would receive $10 \mathrm{~kg}$ of flour for his mother. ${ }^{56 "}$ This case found its way into the records as Wagner complained about the strict controls at the internal imperial borders, where border guards regularly withdrew gifts from the foster families. The Hungarian border guards controlled many of the child transport trains and even threw the food gifts out of the window. Most probably this was due to the rationing of food that was introduced in the Hungarian kingdom during the last years of the war. ${ }^{57}$ Wagner pleaded to stop this type of border control: "If they deprive now such an obedient little boy from this little sunshine, which he would like to bring home in form of flour, it 
would be for such a kid a barbarian bitter-hard life experience. ${ }^{58}$ " He further argued that it would be an amazing happiness for the German home if not only its newly well-fed children but also "pure Hungarian flour or a piece of bacon, which many Reichenberg families do not even know anymore, would find its way into the local hunger homes. ${ }^{59}$ " The herein apparent inequality of food supply between the industrial German areas and the Hungarian rural areas indicates that the Hungarian countryside was much better off than other regions. This changed drastically once the war and the blockade of food imports to the Central Powers had ended. But prior to this, children from urban and industrial neighborhoods would still be sent to less affected areas.

In competition with the internal child transports, transports across the imperial border also took place in the summer of 1917 and afterwards. The Austro-Hungarian People's Nutrition Office organized a first migratory program, namely the "Children to Switzerland ${ }^{60}$ " activity, to improve children's feeding situation for a few weeks. Because of its neutrality, Switzerland remained a rather unburdened destination. Child transports took place throughout 1917 and early 1918, but were soon critically viewed by the Swiss printed media as well as by the imperial authorities. The Swiss public stressed the fact that Switzerland should take care with wasting its remaining resources on strangers. In 1918, the foreign ministry of the Austro-Hungarian Empire quoted an article from the Neue Züricher Zeitung, in which this problem is addressed: "What if all surrounding countries would send their needy children to Switzerland. [...] The anyway meager daily bread of our own people should not be reduced any further. Facing our food and firewood supplies we have anyway far too many foreign people in the country. ${ }^{61}$ " Imperial authorities were therefore pushing to discontinue the transports in order not to overly strain their diplomatic relations with Switzerland. ${ }^{62}$ They also feared that the extensive internal child transports that were planned for the summer of 1918 could loose their relevance.

In the framework of its Summer Holiday Action ${ }^{63}$ in the summer of 1918, the Kaiser Karl Wohfahrtswerk sent about 20.000 poor Hungarian children to the Adriatic seashore, where Abbáziá [Opatija], Lovrana, Volosca, and Portorose [Portorož] were especially popular destinations. While many Hungarians were sent to the Austrian seashore, many Austrian children were sent to the Hungarian countryside. ${ }^{64}$ Most of the children were accommodated in temporary foster families, ideally in farmer families who could offer nutritious food. ${ }^{65}$ Kaiser Karl also provided a number of vacant castles in various regions of the Austro-Hungarian Empire to accommodate the children. He appealed to the clergy and the aristocracy to open their empty provincial castles to the poor children. A newspaper article from 1918 identified the potential of these neglected castles, of which "nowhere in the world we can find so many". The author suggests that in the castles, "which lay among the spruce forests of Bohemia, Transylvania, and the Carpathian Basin" and especially "[i]n the empty ballrooms of these locked castles a yet undiscovered treasure is hidden: fresh air, mountain air.6" some children were accommodated in these castles, but the temporal integration into foster families was far more widespread. The Austrian ministry believed that "the future development of those children, who had severely suffered from a lack of nutrition, could be eased. ${ }^{67 "}$ Sending children either to the seashore or to the countryside resulted from the wish to evacuate them from the major cities, which had suffered most from the war. 


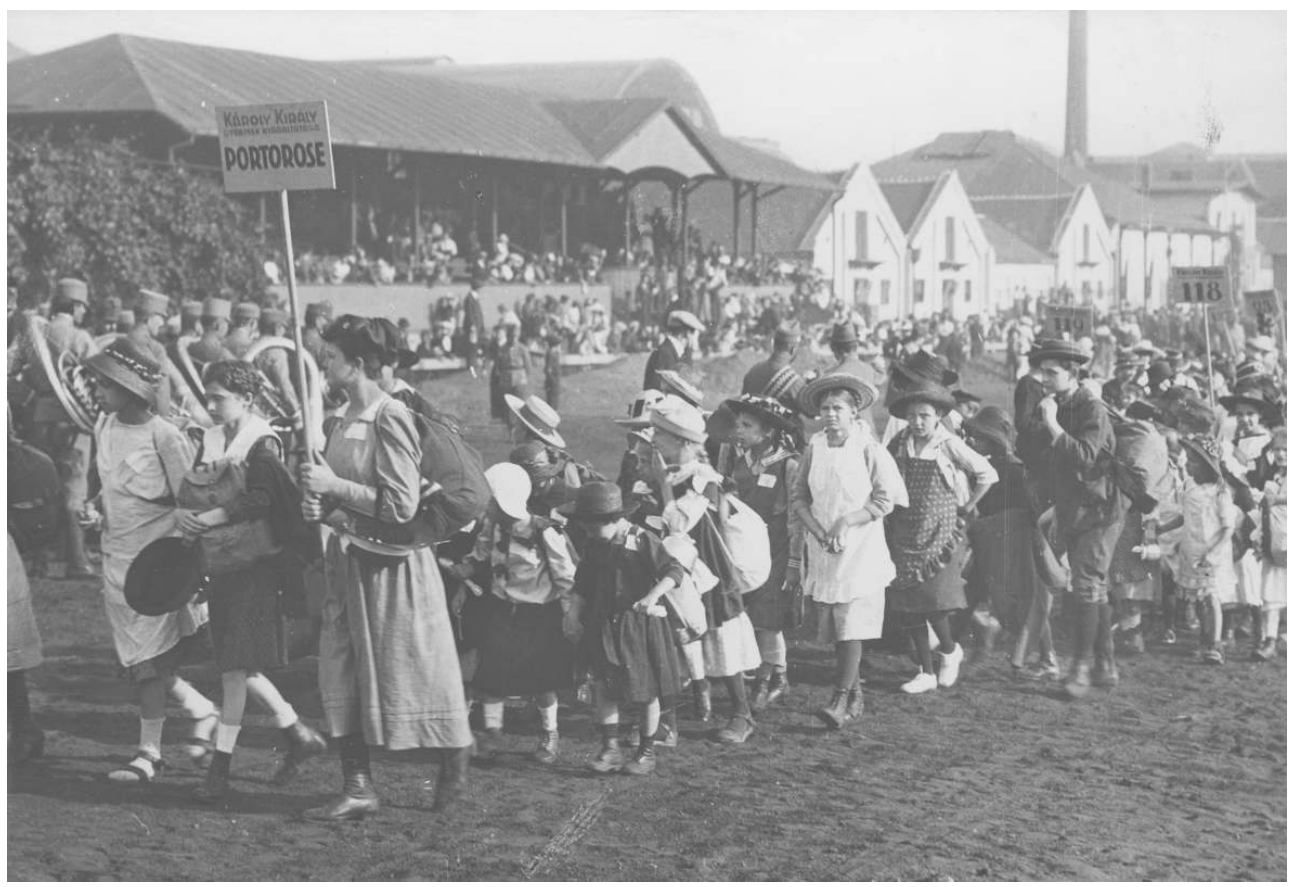

Müllner János, “Departure to Eastern Train Station”, Budapest, 1918.68

"Children Getting on Train"

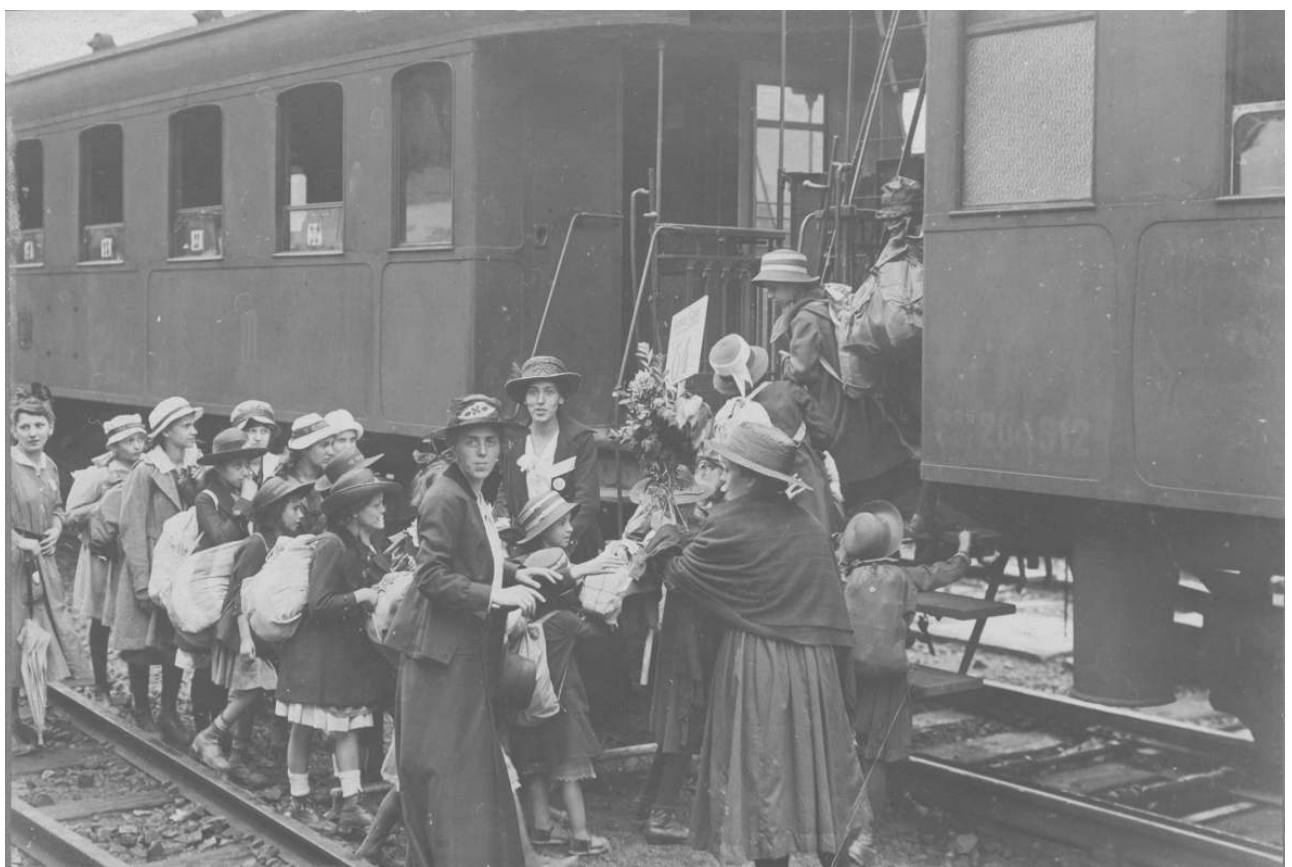

Müllner János, “Children Getting on Train”, 1918.69 
"On train"

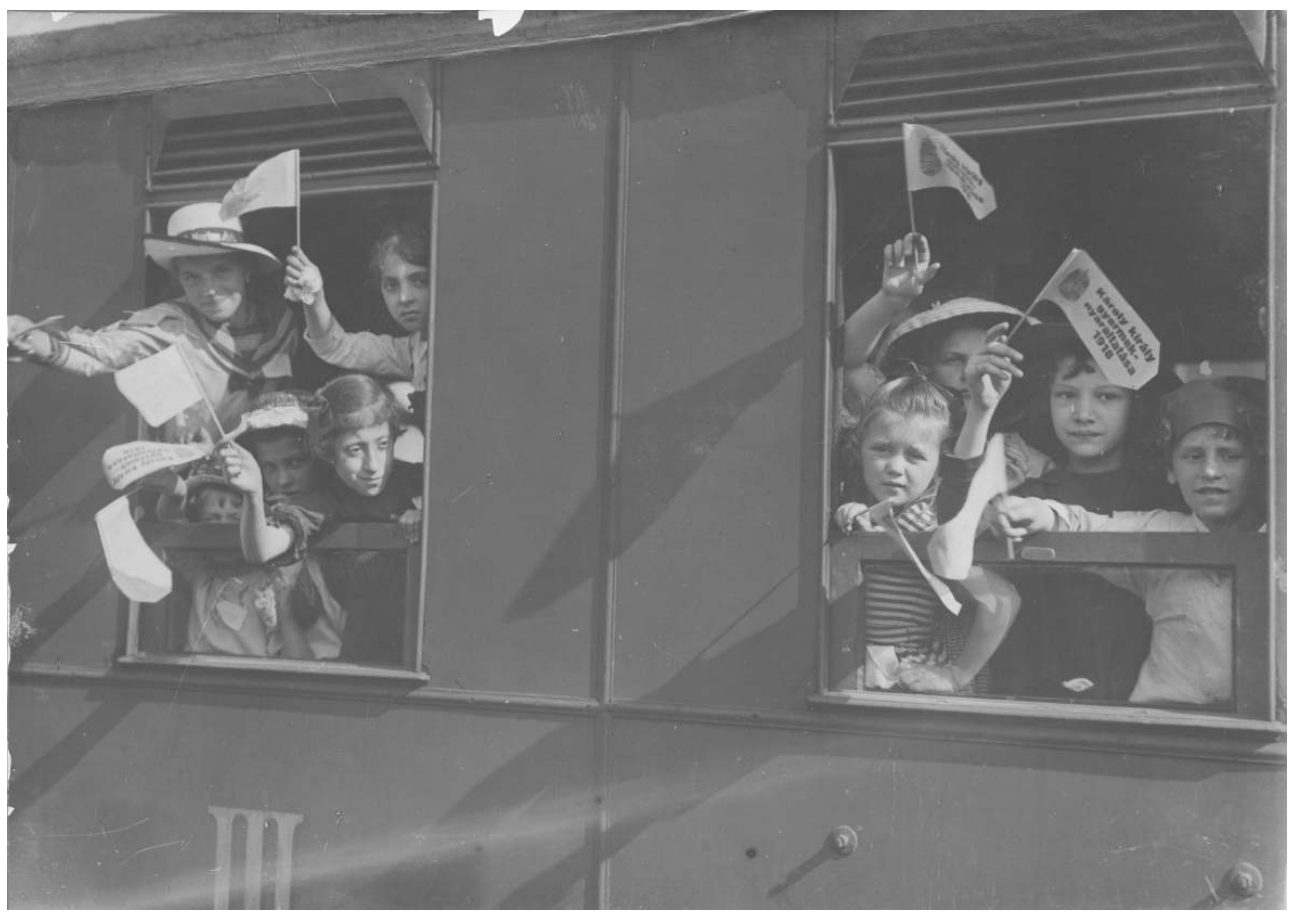

Müllner János, “On train”, Budapest, 1918.70

"Austrian Children Departing to Hungary at the train station in Vienna"

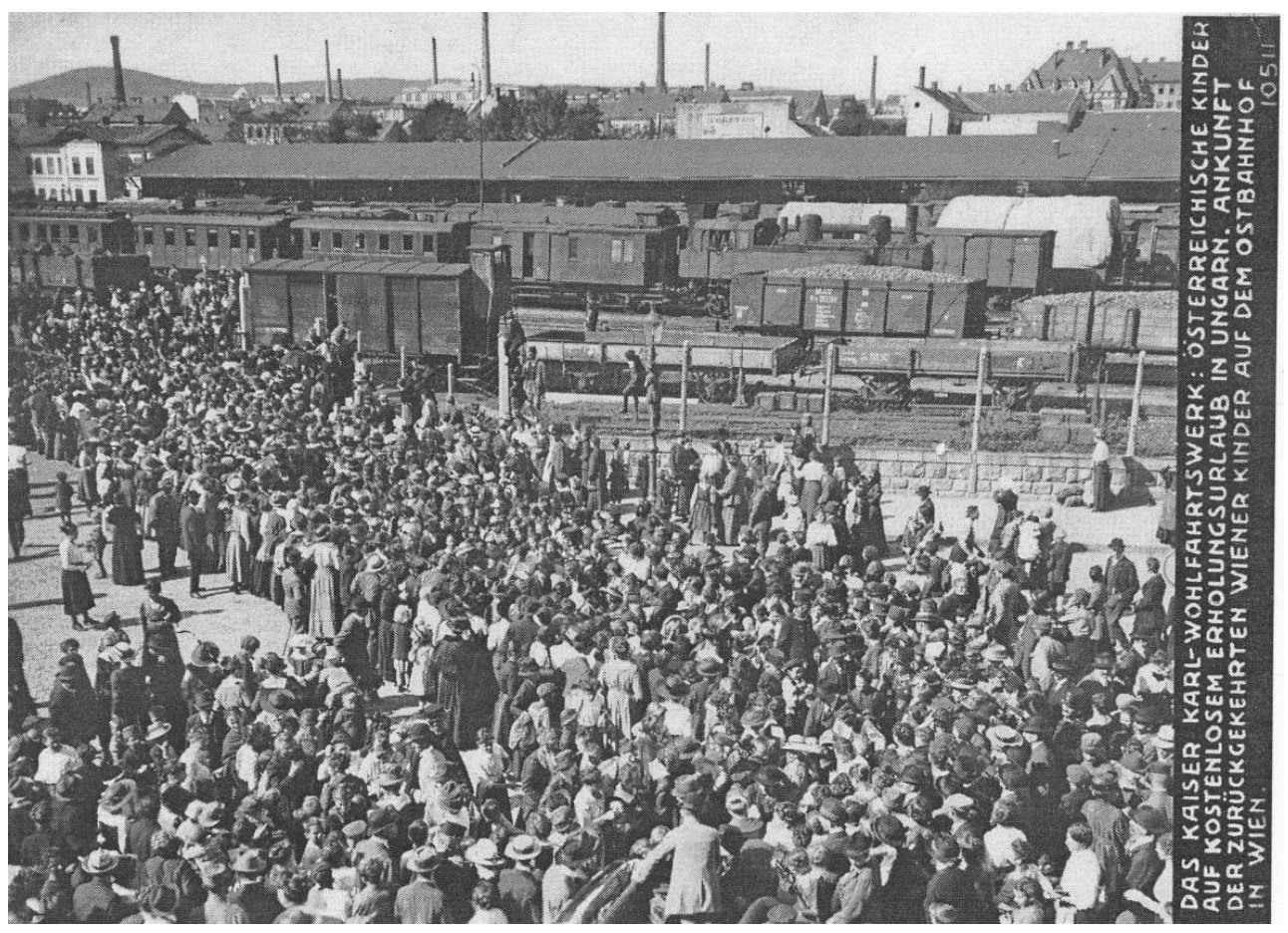

"Austrian Children Departing to Hungary at the train station in Vienna", 1918.71

The child relief campaign targeted middle-class children who had been impoverished during the war and whose bodies showed signs of starvation and neglect. In the aftermath of WWI the scientific study of nutrition and starvation became even more professional, 
relying on the expertise of nutritional experts and special commissions. As a response to the severe malnutrition and famine in the immediate postwar period famous nutritionists like Max Rubner, Ralph Kellor or organizations like the Rockefeller Foundation or the League of Nations conducted research in Central Europe, seeking knowledge on the physiological basis of nutrition. ${ }^{72}$ As "under the pressure of the war, and the economic crisis, food production and consumption became a state responsibility," there emerged the need to know more about the link between malnutrition and certain diseases. Nutritional science often led to straight criticism of international politics. Having developed his own concept of the ideal, meaning "rational nutrition" in prewar Germany ${ }^{73}$, Max Rubner criticized the Allied Powers in the immediate postwar period for starving out the former enemy by means of their "hunger blockade. ${ }^{74 "}$ But before their nutritional science resulted in food distribution programs to protect the health of the various nations, during the war the Austrian Wohlfahrtswerk sought less scientific solutions to counter children's malnutrition. It considered it its task "to send feeble and undernourished Austrian children to Hungary, whereas a large amount of sick Hungarian children shall take residence at the Adriatic Sea. ${ }^{75}$ "Sickness, however, was meticulously defined so as to prevent the spreading of contagious diseases: "Only such children shall be taken into consideration, which are anemic and feeble, but by no means afflicted with any diseases, particularly not with any kind of contagious illness, tuberculosis, dross, etc. ${ }^{76}$." Thus, the relief activities were bound to the criterion of health, and those children whose health had suffered most severely from the war, through contagious illnesses, were not allowed to participate. Apart from the children's health condition, appropriate clothing and hygiene were further preconditions for their participation. An instruction leaflet "for the parents or their representatives" from 1918 determined the conditions for a child's physical appearance, requiring first of all that " $[t]$ he child has to appear at the station at the appointed hour with his gear washed clean and nicely dressed," and secondly that "[c]hildren contaminated by vermin will not be able to join. ${ }^{77 "}$ Here we see some of the ambivalence of the child transports. While only underfed and suffering children were meant to participate, they were required to appear at the train station in an impeccable condition. The moment of the children's departure was not to be overshadowed by the visible strains of the war. 
"Needy Hungarian Children in Austria. Sunbathing"

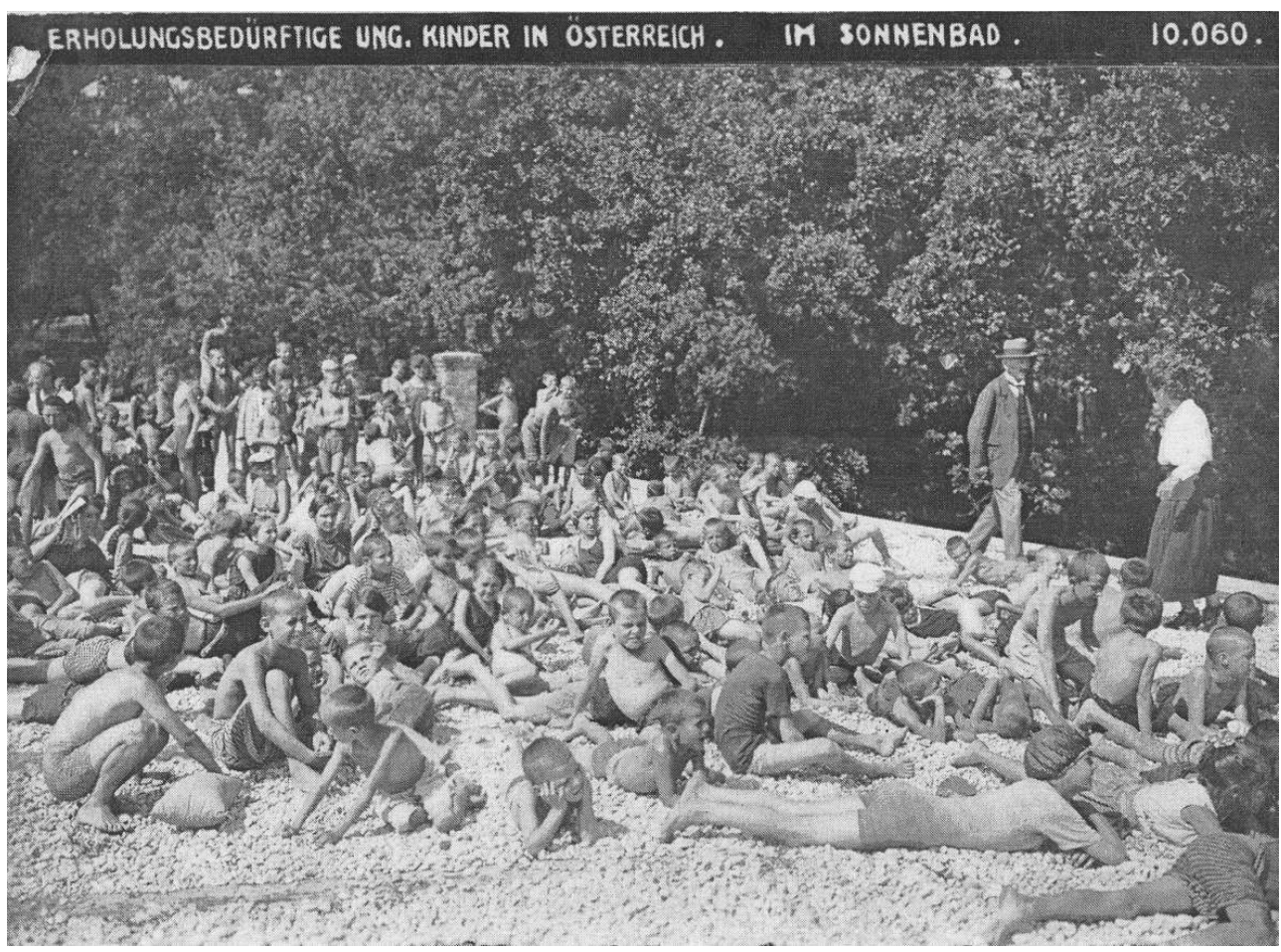

"Needy Hungarian Children in Austria. Sunbathing", 1918.78

"Hungarian Children on Summer Vacation in Austria. Morning toilet"

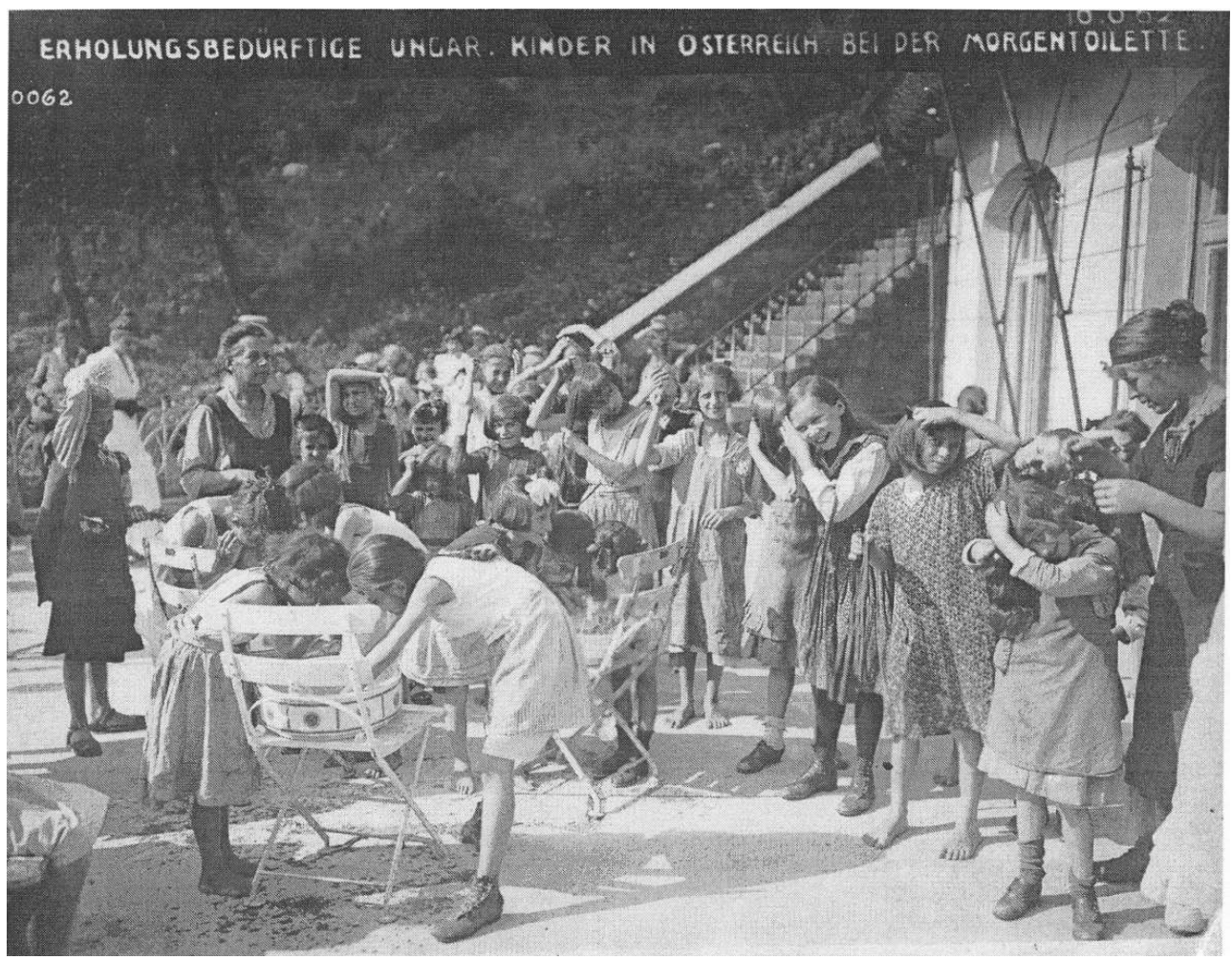

"Hungarian Children on Summer Vacation in Austria. Morning toilet", 1918.79 


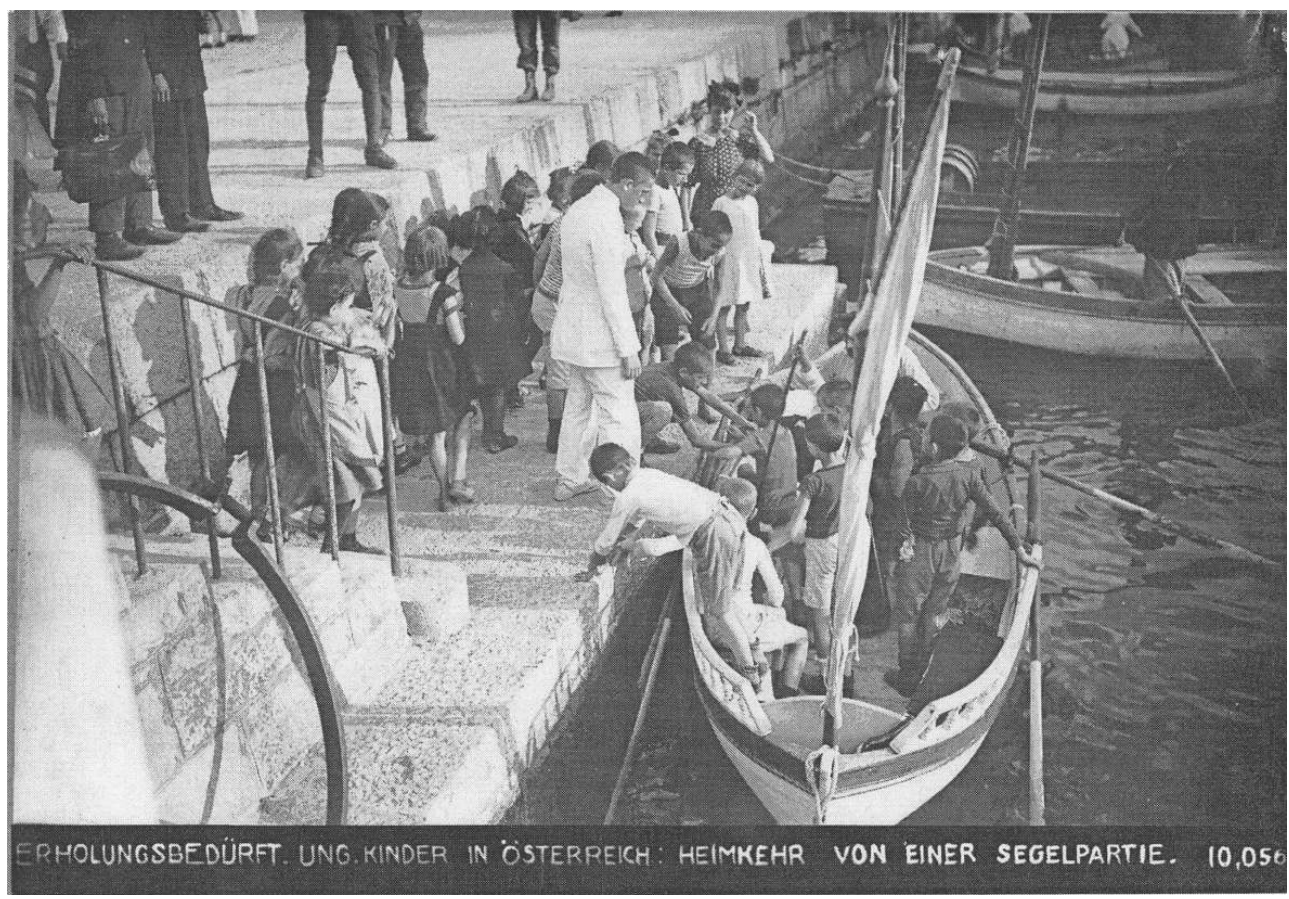

"Hungarian Children coming back from a boat tour", 1918.80 war, they presented an entirely peaceful situation. Activities such as lying on the beach, taking sunbaths, and swimming in the sea or everyday practices of physical hygiene, including hair brushing and washing were documented. Doctors and nurses were always part of these holidays to supervise the children. These idealized summer images created a strong counter-image to these children's often otherwise devastating war experiences. These visual sources represent a situation that calls to mind a nice and exclusive summer holiday, without any traces of the war's impact on the children's appearance. The visual propaganda provided ideal images of childhood that stood in sharp contrast to the children's actual everyday life during the war. In the discourses about the child transports, it becomes apparent that children's physical needs had become a public concern. Texts about nutrition, health provisions, hygiene, clothing, living conditions, and environmental issues accompany most of the images. Important elements of these "war holidays" were "a change of air and surrounding, [...] social contacts with other children, sun and air baths, physical exercise, healthy appetite, new clothing, and a better development of bones, muscles, and blood. ${ }^{81}$ "

Beyond these aspects of health, hygiene, and appropriate clothing, the Kaiser Karl Wolfahrtswerk interfered even more extensively with the private lives of the involved children and their families. The stay with the foster parents was not supposed to be interrupted by any contact with the birth families or other unwanted guests. An advertising leaflet for the "Kinder aufs Land"-activity indicates that "[a] visit of the children in the countryside [by the parents] must be avoided at all costs, because it means an unwanted nuisance to rural residents. [...] If unauthorized visits take place, the children will be immediately returned to their parents. ${ }^{82 "}$ It seems that the stay in the countryside not only pursued the purpose of an improved nutrition and healthy 
environment; it was meant to strengthen children's emotional independence and their social abilities. Some newspaper sources yet indicate some serious troubles with the accommodation and feeding of the foster children after their arrival to the Adriatic seashore. An article in the Pesti Hirlap from August 4, 1918 reproaches the Austrians for their disorganization and the apparently unequal implementation of the 'child holidays' in Hungary and Austria: "A minor incident disturbed this advertisement holiday, through which the lousiness of the whole organization turned out: they [the Austrians] did neither think of the accommodation nor of their feeding. ${ }^{83 "}$ "The debate not only covers a fight over the questionable quality of the Austrian child relief, but it equally uncovers mutual nationalistic prejudices and stereotypes.

Yet, in the public journals of the time it is reported that those children who participated returned physically strengthened. Much emphasis was placed on physical exercise and hygiene. Tibor Vadnay, the summer action's former commissioner of administration, remembered that the "children returned home with a body, which had significantly gained in strength and weight, been trained through the swimming, tanned through the sun bathing, and with a rosy complexion and in [a] good mood. ${ }^{84}$

Apart from increasing the well-being of these children, Kaiser Karl seemed to have simultaneously pursued a political aim. Correspondence of the Kaiser Karl Wohlfahrtswerk indicates that Kaiser Karl had hoped to strengthen the bonds between the increasingly disconnected crown lands as well as strengthening the severely afflicted monarchy. Visually connoting their power with children's secured destiny, which the war had turned questionable, served to counter the fading power and support of the royal couple among the people.

"The Royal Couple among Children"

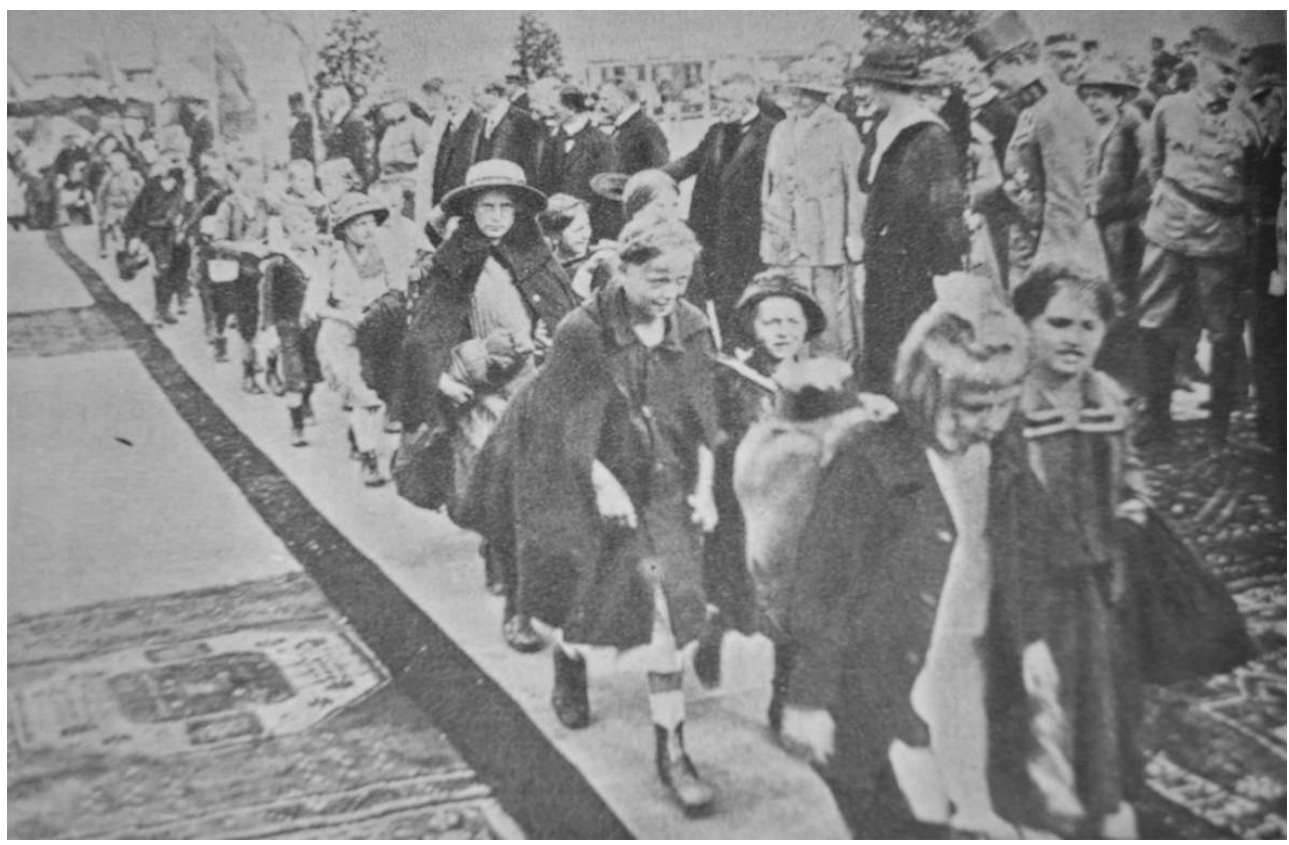

"The Royal Couple among Children", 1918.85

Even if, in the summer of 1918, the dissolution of the Habsburg Empire was not yet decided, clashes between the various nationalities of the crown lands had become apparent. As a possible means to divert this development, the Wohlfahrtswerk hoped "to 
allow needy boys and girls of school age [...] from major Austrian and Hungarian cities and industrial centers, irrespective of ethnicity and faith, to stay in the countryside for several weeks. ${ }^{86 "}$ These child exchanges were meant to maintain the "cordial relationships between the Austrian and Hungarian population, which had been that much intensified through the Kaiser Karl Wohlfahrtswerk. ${ }^{87}$ " The transfer of children across the crown lands was intended as a means to overcome the alienation and conflicts between the various nationalities of the Empire. The suffering child became a handy tool to push for intra-imperial exchanges. Maureen Healey convincingly demonstrated how vitally important the idea and the symbol of the "imperial child" was in the last years of the empire, offering an idealistic counter-image to the increasing inner turmoil across the empire. Healey argued that the imperial child discourse believed that "children were a political tabula rasa, unaffected by the nationalist, class and religious discord of late imperial Austria," whereas in reality "the apolitical, supra-national Austrian child [as a symbol] was weakened by forces that had already claimed children as political weapons in the Empire and within Vienna itself. ${ }^{88}$ " Already within these intra-imperial exchanges, national competition became obvious. Vadnay remembers the inherent, though still friendly, competition between the temporary foster families:

"The same as in the good old times of abundance, they entered into a competition with each other about who would be able to fatten his/her "small German" better. All of the small Germans who arrived here pale, meager, anemic, and sick, gained kilos, regained a healthy complexion, and became exhilarated and happy from the Hungarian bread, the Hungarian air, and the Hungarian kindness of the heart. ${ }^{89}$

Hungarian bread gained the almost messianic significance of a holy host, allowing for the physical redemption of the poor and suffering Austrian children. By "gloriously exhibit [ing] the noble hospitality and child love of our blessed Hungarian nation ${ }^{90}$," the summer action uncovered the intensifying tendencies of nationalism as a driving force behind the child relief activities.

A few months later, the dissolution of the empire became a fact. While countries such as France were severely damaged through the war itself, a report about the situation in Hungary from 1920 suggested that "Hungary is a country which has suffered far more after than during the war.91" Its post-war destiny affected its geographic, social, and political identity. After the new borders had been decided upon at the Paris Peace Treaty, one-third of ethnic Hungarians found themselves outside the political borders of the Hungarian state. A contemporary observer emphasized in a letter to SCF that the "whole economical life of [the] [...] country has been paralyzed by the loss of the war, by the invasion of the enemy, by the dismemberment of the body of [the] [...] country, which is no longer a geographical unity. ${ }^{92}$ " The simultaneity of the loss of the war and the imperial collapse had discontinued much of the prewar social welfare system. Yet, the selfreflection concerning the failure of the public and private welfare organization to provide the needed aid for children quickly found various public outlets. Particularly after the war had ended, the everyday life of children was closely documented in national and international journals and newspapers. In a New York Times article from 1920, entitled "Starving Budapest: Capital of Human Misery," the situation in Budapest was judged as most disastrous. In public debates, Hungary was represented-apart from the Soviet Union-as the most war-affected country: "All Central Europe is a bleeding wound, but nowhere, perhaps, is life so poor a gift as in Austria and in Hungary. ${ }^{93}$ " Another newspaper article in a Hungarian journal of the time depicted "the help-seeking misery," documenting the daily life of children in Budapest. Ten images were assembled in order 
to draw attention to the devastating situation of children in Budapest, who sought immediate "help" from abroad. They address the overall issues affecting the children's lives: a lack of housing, poor living conditions, child neglect, homelessness, child labour, children's threatened health and lacking health care, and a lack of clothing and food. In a report for the SCF about "How is life in the capital?," Endre Liber, a contemporary Hungarian observer, paints a very dark picture of children's life in post-war Budapest, seeing it as a main cause for the city's ongoing criminalization:

"[T]he investigation/razzie of children organized by the Children's Tribunal of Police shows us the fearful misery of the children of our capital. [...] [T] he miserable children lay in their empty beds without any clothes. [...] [There is an] increase in the number of those demoralized or of needing and abandoned children [...], who came before the Children's Tribunal of the Police. [...] It is sad to state, that there are several among the children, arrested [...], who belong to the families of the middle class. ${ }^{94 "}$

In this and other contemporary sources, Hungary, due to the loss of a great part of her territory, is presented as a victim of the war and its postwar developments. As the Hungarian migration from Transylvania caused above all an "elite migration" 95 "-many of the refugees were highly educated and financially secure-the social decline of this group became more obvious than that of others. Liber tends to present Hungary and its middleclass as victims, because to him "the poor Hungarian population, especially the middleclass [came] guiltlessly [...] into [its] present miserable situation, not being able to secure, in spite of forced working, the daily bread for themselves and their families". Therefore, he pleads for solidarity with the middle class, which "now more than ever needs the beneficent help. ${ }^{96 "}$ The suffering of the middle-class, first of all of its children, was meant to be relieved. Their physical state prior to the examination was important. In a little booklet from 1920, the Hungarian socio-photographer and police reporter Tábori Kornél reported, after an "inspection tour through the misery of Budapest", that "after the horrors of the war and two revolutions, the city went through the Bolshevik times and the Roumanian occupation." He compares the situation of Budapest and Vienna, and concludes that even if Vienna had not shared these last mentioned catastrophic experiences, "it made its well-deserved claim for pity known throughout the world [sic]. ${ }^{97}$ "He therefore pleads for equal, if not greater, international mercy with Budapest. The booklet's cover image, subtitled "From the Horrors of the War9s" shows a kneeling emaciated mother, surrounded by a crown of thorns, who holds her starving and headshorn child up into the air. While the mother closes her eyes as she gives her child away, the child is depicted with open arms. This image underlines the overall purpose of Kornél's booklet in two ways: on the one hand, it visualizes the horrors of the war, while on the other, it depicts a mother who tries to protect her child from the horrors of the war by giving it away. The mother, but also the image as a whole, appeals to the international humanitarian community "[t]o help and save the children. ${ }^{99}$ " As this image shows, aid imagery often relied on a "dynamic of abstracting children from their historical, cultural and political location, as already inscribed within dominant ideologies and cultural representations of childhood. ${ }^{100 "}$ In this depiction the child and the mother are visually reduced to a single experience: the physical experience of hunger. Their being is that much determined by the lack of food, that a life together appears impossible and the international savior comes into play.

Due to the disastrous situation in Budapest, national child relief was severely impaired. Although Hungary had been an enemy during the war, international relief was provided 
once the Soviet Republic had come to an end in the summer of 1919. Andrew Cherna, the Honorary Commissioner of the American Red Cross, reported in 1923 about his trips to Budapest: "Poverty wherever I meet it, has the same distressing effect upon me. The deterioration of the human soul and body touches me as a pathetic canvas, irrespective of nationality, race, or environment. ${ }^{101}$ " The International Save the Children Union recognized in 1920 that "hardly any help from National Relief organizations [could] be counted upon, because provisions and clothes are lacking, and cannot be brought in the country, and they themselves depend largely on gifts from foreign missions. ${ }^{102 "}$ "For that reason, the Hungarian national child relief organizations sought help abroad, as a report from 1936 about the past thirty years of work of the National League of Child Protection, namely the time between 1906-1936, states. In this report Fülp Rottenbillder, the under-secretary and "president of the controlling agency of the minor" in 1936, recalls the shift from national to international support in the child-saving movement of the time:

"Undoubtedly the greatest challenge had been that [...] this [Hungarian] society, which had supported us with great love for decades, was so occupied with its thoughts about its everyday survival, that it had become unimaginable to practice charity. We had to acquaint the foreign countries, which were seeking to provide help, with our projects, institutes and institutions. We also had to draw the attention of the foreign countries to the sad conditions in Hungary. ${ }^{103 "}$

The report's author interprets the abrupt lack of national charity as the direct consequence of the people's severe problems with securing their everyday livelihood. In a letter from 1920, Julia Vajkai, who headed the National Child Protection League in Budapest, wrote to Eglantyne Jebb at the SCF, pleading for financial support, as the "Child Protection League [...] is doing splendid work, and has 3.000 children in child care in its asylums and homes." She points out that if the League would not receive any support, it would need to shut down and " 3.000 children would be put on the street; those many and many thousands who already are victims of criminality caused by hunger and utter privation. 104" She closed her letter with a request: "Dear Mrs. Jebb, I implore you to use all your influence and help me to get this money. ${ }^{105 "}$ "The SCF decided to support Mrs. Vajkai, and even invited her to study and to report on the situation of British child relief. She became a local authority on the implementation of international relief in Hungary, and was regularly praised for her accomplishments in Budapest. In a report to the SCF from 1926 "[ $t$ ]he results achieved by Mme. Vajkai up to the present" are recognized as having "had a wonderful effect on making slum children into good citizens." Therefore, the author strongly argues, "[t] here is no reason why Mme Vajkai's devotion should not, with the support of the SCF, achieve even greater results. ${ }^{106 " ~ C h i l d r e n ' s ~ u n i q u e ~ v a l u e ~ a n d ~}$ power as "the" future citizens of the nation is emphasized here to further empower local child relief. Strengthening the local relief organizations had been developing into a new strategy of child philanthropists as well as politicians. ${ }^{107}$ But without money, Julia Vajkai would not have been able to accomplish much.

Tábori Kornél addressed the money issue equally openly: "We need the help of those who are better off than we are, who have not suffered so greatly, and whose money has not lost its purchasing power as ours has. ${ }^{108}$ " The lack of money and medical equipment brought national relief almost to a full stop. For SCF, it was of utmost importance to train social workers in Hungary and, in this way, to turn them into multipliers: "All relief work should be organized so that as much as possible the actual work should be done by Hungarians themselves, under supervision and control. ${ }^{109}$ " With the help of the SCF, workrooms and feeding stations were installed, clothing shipments were distributed, and 
medical care was provided. In addition, temporary housing and education were also provided. Sometimes, families who had profited from the relief activities wrote personal thanking letters to SCF or to Mrs. Eglantyne Jebb herself. In one of these letters, a family named Horak identified itself as having suffered greatly from the war, saying it had only been rescued through the funding and housing of the Save the Children Fund:

"We are always thinking gratefully of those who helped to get homes for us poor war invalids and widows with our families. May you be as happy as you have made us. [...] We beg the Almighty to pour his blessing over you and your family and give long life and happiness to those who provided us with a home. [...] This will be our prayer on this holy Christmas eve. ${ }^{110 "}$

Many such families, and in particularly refugee families, received the opportunity to send their children abroad for a certain amount of time. From 1920 onwards, international child relief agencies, in cooperation with national relief agencies, sent around 60.000 impoverished Hungarian children to foster families in the Netherlands, Switzerland, Britain, and Sweden, with Belgium joining in $1923 .{ }^{111}$ The activity was financially and practically supported by the SCF and the ICRC, and organized in Hungary by the National Child Protection League. Placing poor Hungarian children into better-off foster families abroad was perceived as a sensible act of relieving their suffering. A report of the National Child Protection League from 1936, on their so-called "foreign children holidays," claims that this activity had been "the most interesting chapter not only for the reports of the years 1919-1920, but in the entire life history of the Hungarian League of Child Protection." It states that this "wonderfully succeeded mass action," although it had actually contributed to the better understanding of the nations, its "contemporary impact may never be recognizable or appreciable. ${ }^{112 "}$ Therefore its author elaborates in detail on the various children's trains and their long-lasting impact not only on the physical strength and health of the children. But apparently equally important seems to have been its effect on the advancement of international tourism as well as on the national economic situation in Hungary of the time. 


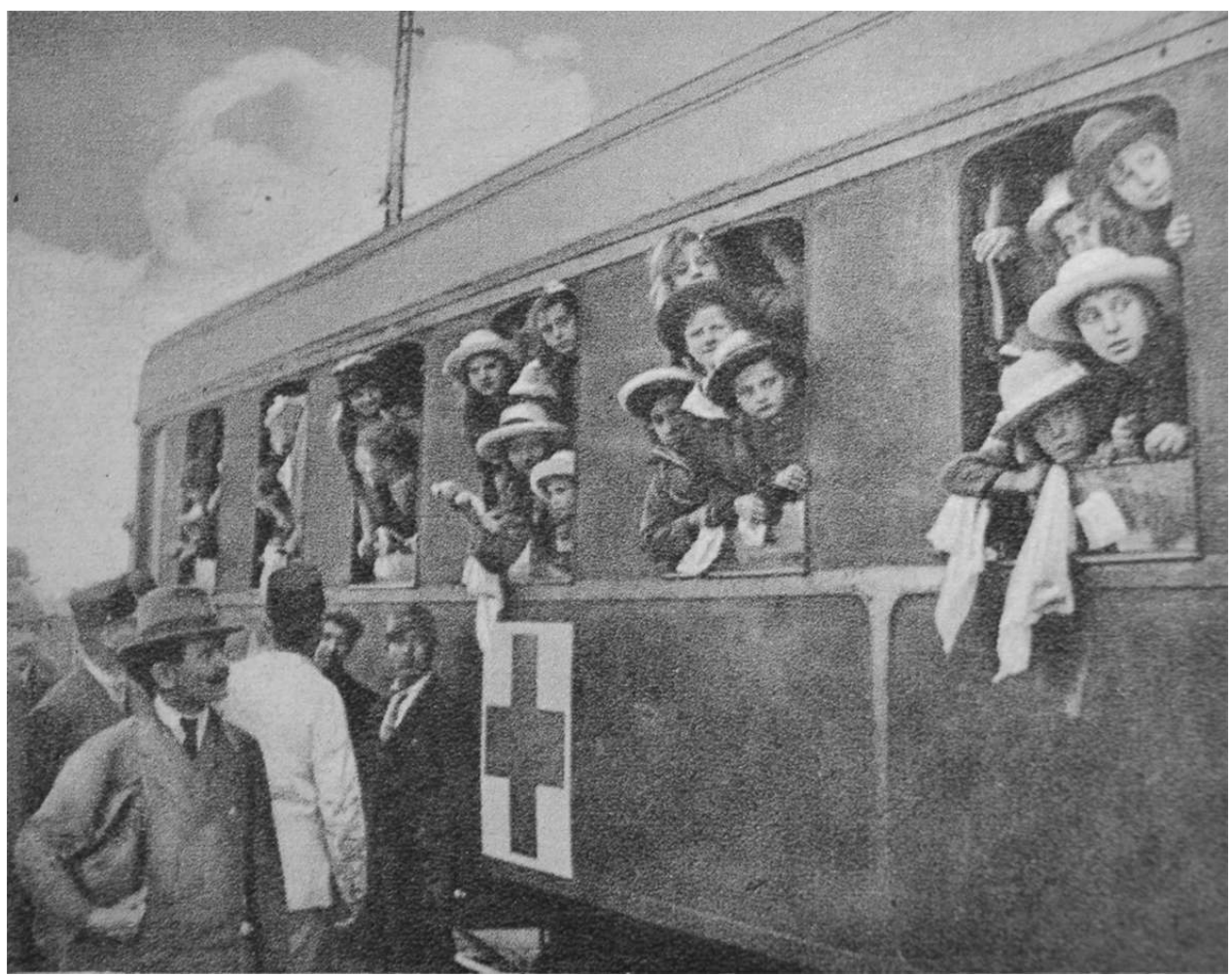

"600 Hungarian Children arrive back from Holland", Budapest, 1921.113

These child transports to foreign countries were partly a reaction to the disastrous economic situation in Hungary, but they were also due to the fact that with the Treaty of Trianon, Hungary had lost access to the Adriatic Sea. Thus, the option to send children on a summer vacation at the seashore or to the mountains in Transylvania had ceased to exist. Therefore, international child transports offered a good, and also economically attractive, alternative, as the state institutions found themselves in a precarious financial situation and were thus very badly equipped. Making use of the international relief and help allowed them to overcome these most dramatic years of post-war distress. Yet, sending one's children to families in the former enemy countries, only a few years after the fierce and brutal conflict between the Allied and Central Powers had ended, appears like an incomprehensible act of transnational reconciliation. The children served as a means for a personal rapprochement between the former enemy populations. In order that the children could be allocated to foster families, the National Child Protection League selected the children and the foster families. They then distributed declarations that even foresaw that parents could allow their children to remain in the foster families once the "international holiday action" was terminated. ${ }^{114}$ The child transport lists often show blank spaces in the field for the children's return. The children arrived by train and were welcomed by and integrated into the foster families. 


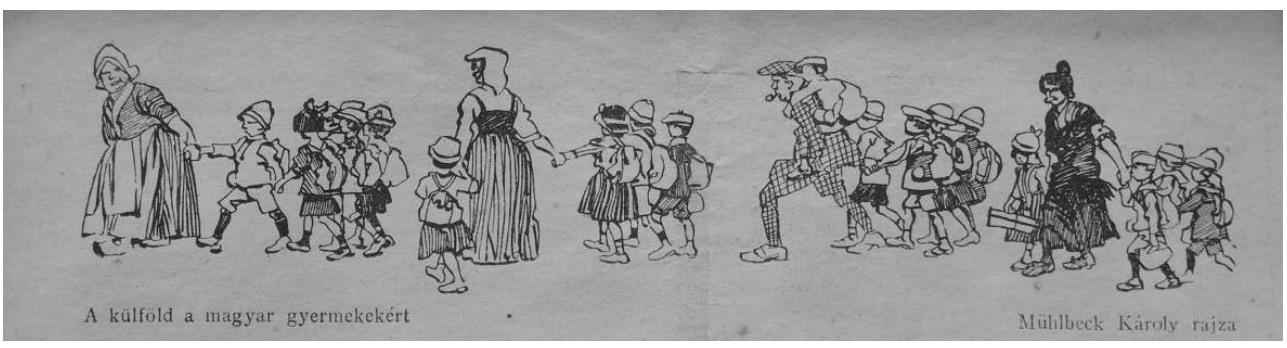

"Foreign countries for Hungarian Children", 1920.115

In this picture, subtitled "Foreign countries for Hungarian Children" ${ }^{116}$, national iconic foster parents are depicted in the moment of the children's arrival in the host countries. Placing four national representatives of this child relief endeavor together, the picture captures the internationalist character of the post-war child transports. The image presents, on the left side, a typical Dutch farmer woman; next to her, possibly a Swedish foster mother; then a British gentleman in a checkered suit and cap with a pipe; and on the right, a Swiss foster mother. Each foster parent drags away four to five children between the ages of four and seven. The children are thin but well dressed, and they carry their own luggage. While the four foster parents drag the children in various directions, indicating the broad international character of the action, the children appear as passive objects. Child transports provide relief for the children's suffering, but their agency is reduced to the minimum.

The Kindertransporte were originally meant to provide short-term relief, and not to extend a period of six months. They sometimes resulted in the long-term placement of Hungarian children in foster families. As has been shown by Vera Hajtó, in the case of the transports to Belgium, around 5 to 10 percent of the children never returned to Hungary, but instead settled in Belgium. ${ }^{117}$ This development was not restricted to the case of Belgium. It often depended on the circumstances of the children's birth families. The greater the economic cleavage between the birth family and the foster family, the more likely it became that children would not return home. This resulted in the loss of an unknown number of Hungarian children to foreign countries. A number of such cases can still be uncovered through personal letters between the National Child Protection League and the involved families. A letter by the Hungarian Secret Counselor from June 1, 1940, to the Hungarian Tax Office documents the individual case of two children who had remained abroad for twenty years. After their father's death in 1920, the two daughters of Lajos Tamás, Irén (born in 1907) and Zsófia (born in 1912), were sent to Dordrecht in the Netherlands, where they established good contact to their foster parents, who "started to love them, raise them and care for their future. ${ }^{118 "}$ "The father's death in 1920 and that of their mother in 1932 made them into full orphans, preventing their reintegration into their birth families and thus their return to Hungary. As "nobody belongs to them [in Hungary] [and as] they forgot their mother tongue entirely ${ }^{119}$," the letter requests a confirmation of the children's identity and citizenship so that they would not be expelled from the Dutch territory. This case shows that the children's relocation was often a reaction to their abandonment. Orphans and semi-orphans were prime targets of the endeavor. 

physical well-being of the targeted children, their relocation yet represented a high degree of public interference into the lives of families and children. Humanitarian groups prioritized physical wellness above the children's emotional condition, which was naturally strained in the new foster homes. Against this backdrop, the original intention of child relief activities sometimes differed from their actual short-and long-term (social and emotional) impact on children's lives. In an article entitled "The Black Outlook in Europe," a British reporter dared to seriously question the appropriateness of the child relief undertaking. Praising the charity of the Dutch and Swiss host families, he also addressed the problems involved in the separation of children from their families: "Yet I doubt if as a child I should have liked to be sent among perfect strangers not one of whom could understand what I said, and the majority of whom would regard me, and probably treat me, as a little enemy. ${ }^{120 "}$ In his children's book 'The Adventures of Liga Gida' [Liga Gida Kalandjai], Gyula Krúdy recounts how Gida, the book's main character, hopes to prevent the dreaded medical examination of the relief doctors. "I know a grass on the old Rácvárosi cemetery with which I can rub my face and my hands so that they turn yellow [and] the doctor will lose his interest in the [...] examination. ${ }^{121}$ " Gida wants to be rejected, because he does not want to leave his family and go abroad. However, he has to join the transports.

36 As the child transports mostly originated either from a religious or a humanitarian background, taking a poor Hungarian child into one's home was considered an act of solidarity and compassion. Frida Victor, a Hungarian teacher who had accompanied the transports to Holland in the early 1920s, recalls in 1928 how the Netherland's "deep religiosity warmed up [t]he peaceful, orderly and healthy Dutch family life. ${ }^{122 "}$ The reports are full of detailed descriptions of the host's overall national characteristics, but the issue of religion is almost always addressed. In the case of Switzerland, Irén Marton, a Hungarian supervisor, acknowledges the everyday presence of religion in one foster family: "The Swiss are also religious, in the family I found almost next to every bed a bible. ${ }^{123 "}$ " Despite the equally difficult economic situation in Switzerland, the Zentralstelle der schweizerischen Hilfsaktion für ungarische Kinder, founded by the pastor Carl Irlet ${ }^{124}$, invited over 16.000 Hungarian children for a stay in Switzerland. In a letter to Eglantyne Jebb from 1921, Irlet outlined his own private motivation. He felt urged to "continue the blessed work of Christian charity" and bring a new convoy of Hungarian children to Switzerland despite the poor economic conditions of his own country". He specially thought of the needs of "the middle class and refugee families in Budapest," which he believed to be "so pressing" that everyone should be "committed in spite of all possible considerations to continue." But because of their tight money situation, Irlet saw no other way than to address himself again to Jebb and the SCF, begging her "to quickly provide help ${ }^{125 . " ~ A n y ~ " b l e s s e d ~ C h r i s t i a n ~ c h a r i t y " ~ h a d ~ t o ~ r e g u l a r l y ~ r e l y ~ o n ~ f i n a n c i a l ~}$ support from organizations such as the SCF, support that was often provided. As the transports were largely funded through the SCF, it is not astonishing that most of the SCF reports about the transports praised the success of the endeavor.

On December 20, 1920, a man called Bohlen wrote a letter to Lord Wardale concerning the work of the British High Commission in Budapest: "Dr. Amstrong-Smith tells me that the children sent to England under the 'Hospitality Scheme' were so carefully chosen that in their case the scheme proved an entire success unlike those sent from Vienna. ${ }^{126 "}$ The relief effort was presented as such a success that foster parents sent letters to SCF asking 
about the ways in which they could to maintain contact with their former foster children. One letter, addressed to Mrs. Vajkai, tells the story of a foster boy from an orphanage:

"We have an enquiry from a foster-parent of last year regarding a boy (card no. 6378), LAJOS VIRÁG, RAKOSKERESZTÚR, near Budapest, Orphanage. The year's adoption of this child ran out last June. The adopter [...] continued to subscribe into this year hoping the same boy would benefit; but it was found necessary after June to assign him a Viennese child instead. He is rather sad about it and anxious to keep up relations with Lajos Virag but has failed to get an answer to a letter he wrote. [... ] Perhaps you could [...] inform us of the child's present circumstances. ${ }^{127}$ "

Sometimes, stays abroad would be repeated if the foster parents were willing to host the child another time. As a "question sheet for children's aftercare committee" from 1922 shows, a close social examination was applied not only to the general, financial state of a family, but also to the long-term effectiveness of the child transports:

"Clean home, well kept. [...] Children, who were in England are visiting the English classes regularly, are corresponding with foster-parents; they are both healthy, one of them anemic. It is a numerous family, so they have troubles enough how to nourish and dress their children. They are middle class people and deserve help. ${ }^{128 "}$

When the children returned from their stays abroad, they would often be equally closely examined. Just as in the case of the Kaiser Karl Wohlfahrtswerk, the physical state of the children would serve to judge the relief effort's impact. A child's increased weight after having passed through the relief program would be taken as proof of its overall success. Many reports refer also to the successful cultural integration of the foster children and their ability to emotionally affect their foster parents. At the same time, the reciprocal influence, made also mutual-and often biased-perceptions visible: "The less temperamental and colder natured hosts right away fell in love with the children and could easily enchant the direct, attached, intelligent, and easily adaptable Hungarian children, who after the deprivations at home accepted with greatest joy the smallest gifts and who could cheer up the mood of the hosts' children. ${ }^{129 "}$ The Hungarian child is presented here as the main motor in the relationship's transformation to the better.

But little is mentioned about the children's possible disintegration from their birth families. As the image, entitled "Here are the Dutch Fathers and Mothers" shows, sometimes-possibly not only language-wise-no difference was made between "foster parents" and parents. The foster parents simply turn here into the children's parents.

"Here are the Dutch Fathers and Mothers"

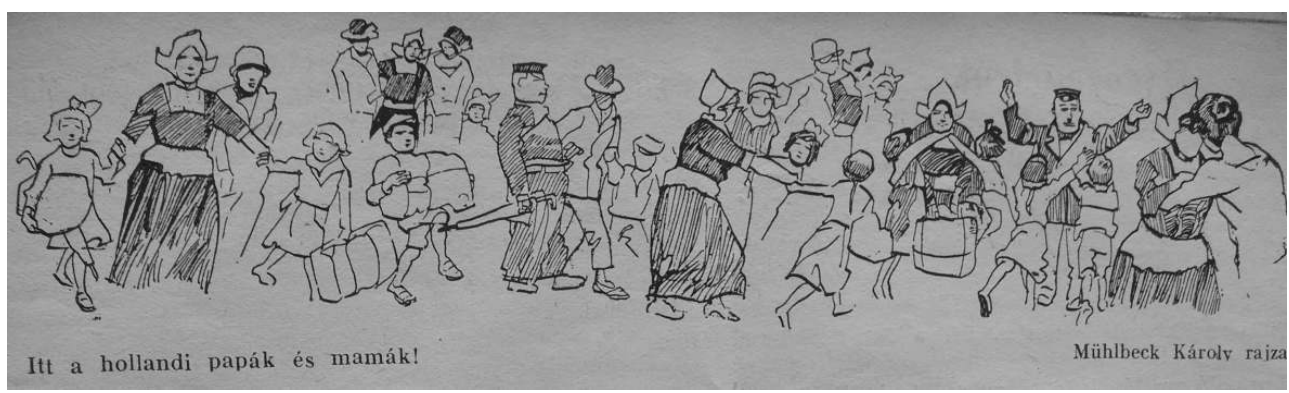

"Here are the Dutch Fathers and Mothers", 1924.130

The little story "Kitty in Holland forgot something"131," published in Uj Idök in 1924, translates many children's experience of alienation and emotional disintegration, triggered through their temporary displacement, into a literary text. During her stay in 
Holland the Hungarian girl Kata had not only changed her name to Kitty, but she had also gotten used to "live there like a little princess. ${ }^{132 "}$ She is not only disgusted by her parents' poverty, which she had simply forgotten; she is neither willing to share any of the gifts from her Dutch foster parents with them. As she does not even allow her father to clean a fresh wound with her new soap, her father abruptly dies from the infection. The story ends with the sentence "Kitty has forgotten Kata's tears ${ }^{133}$," pointing to the fact that the stay abroad had emotionally changed Kata and left her unable to reintegrate into her birth family.

Yet, the imagery of the child transports rarely touches upon any of the problems involved in children's displacement, but employs over and over again images of perfect childhoods to visualize the amazingly humanitarian character of the relief activities. In this way, both the depicted child and the humanitarian organization jointly embody ideals of innocence, purity, humanity, and solidarity. Also the viewer gains access to the emotions encoded in the images. Through the printed visuals in major journals, he/she not only "regard[s][...] the pain of others", but witnesses the relief of pain. "Something becomes real-to those who are elsewhere, following it as 'news'-by being photographed. ${ }^{134 \text { " }}$ Visually witnessing the physical alleviation of the children's suffering that followed their temporary relocation during and after World War I spurred the financial and public support of the ongoing humanitarian undertakings. In the imagery of children's displacement, the individual identity of the single participating child withers away and becomes replaced by a vague collective "child" identity. The depicted masses of relieved children convey the image of a saved childhood; saved at the hands of the "heroic" organizers and the donors. Possibly especially because Hungarian children had represented the former "children of the enemy," the representation of their international humanitarian salvation is idealized. As the war had resulted in large-scale devastation and poverty, the relocation of children offered a symbolic counter-image to the war and its aftereffects. Through the images both readers and donors could identify themselves as heroic child saviors or at least distant witnesses of child saving activities. As the "prevailing functions of humanitarian images remain largely consistent ${ }^{135}$," we are regularly confronted with dichotomist images of suffering and its relief, enabling us to become witnesses-even if only from a distance-of the saving of children. And at that time, foster families who-out of their religious motivation-took up poor Hungarian children for weeks, months or even years, must have surely felt that they would deserve to go right away to heaven. Yet, if you talk to some of the former child transport children, their severe alienation from their birth families was sometimes longer-lasting than their memories of their precious gifts abroad.

\section{NOTES}

1. LUDDY Maria, "Women and Philanthropy in Nineteenth-Century Ireland", in Voluntas 7, 1996, p. 350-364. 
2. DENNESS Zo, "Women and Warfare at the Start of the Twentieth Century: the Racialization of the 'Enemy' during the South African War (1899-1902)", in Patterns of Prejudice, 46, 2012, p. 255-276.

3. MAHOOD Linda, Feminism and Voluntary Action: Eglantyne Jebb and Save the Children, Basingstoke, Palgrave Macmillan, 2009, p. 315.

4. zIMMERMANN Susan, Prächtige Armut. Fürsorge, Kinderschutz und Sozialreform in Budapest. Das "Sozialpolitische Labor" der Doppelmonarchie im Vergleich 1873-1914, Tübingen, Jan Thorbecke Verlag Sigmaringen, 1997, p. 306-307.

5. JONES Heather, "International or transnational? Humanitarian Action during the First World War", European Review of History 16, 2009, p. 697-713.

6. MAHOOD Linda, op. cit; BAUGHAN Emily, "The Imperial War Relief Fund and the All British Appeal: Commonwealth, Conflict and Conservatism within the British Humanitarian Movement, 1920-25", in Journal of imperial and commonwealth history, 40, 2012, p. 845-861; BAUGHAN Emily, “'Every Citizen of Empire Implored to Save the Children!' Empire, internationalism and the Save the Children Fund in inter-war Britain", in Historical Research, 86, 2013, p. 1-22.

7. AUDOIN-ROUZEAU Stéphane, BECKER Annette and SMITH Leonard, France and the Great War, 1914-1918, Cambridge, Cambridge University Press, 2003, p. 137-139.

8. ZAHRA Tara, The Lost Children: Reconstructing Europe's Families after World War II, Cambridge, Mass., Harvard University Press, 2011, p. 30.

9. IRWIN Julia F, "Sauvons les bébés : Child Health and U.S. Humanitarian Aid in the First World War Era", in Bulletin of the History of Medicine 86, 2012, p. 37-65.

10. ZAHRA Tara, op. cit., p. 28.

11. MARRUS Michael and zOLBERG Aristide R., The Unwanted: European Refugees from the First World War through the Cold War, Philadelphia, Temple University Press, 2002; SKRAN Claudena, Refugees in Inter-war Europe, Oxford, Oxford University Press, 1995, p. 51.

12. INGLOT Tomasz, Welfare States in East Central Europe. 1919-2004, New York, Cambridge University Press, 2008, p. 100.

13. KELLOGG Vernon, "In Budapest and Vienna", The New York Times, 1920/03/28.

14. SChUlte Dagmar, "Conclusions, reflections and outlooks. Case studies and their contribution to an holistic history of social work", in Kurt SCHILDE and Dagmar SCHULTE (ed.), Need and Care- Glimpses into the Beginnings of Eastern Europe's Professional Welfare, Opladen and Bloomfield Hills, Barbara Budrich Publishers, 2005, p. 257-292, p. 286.

15. AUDOUIN-ROUZEAU, BECKER, SMITH, op. cit., p. 233.

16. AUdoUin-ROUZEAU, Stéphane, L'enfant de l'ennemi 1914-1918: Viol, avortement, infanticide pendant la Grande Guerre, Paris, Aubier, 2009, p. 181.

17. RIVIÈRE Antoine “'Special Decisions' Children Born as the Result of German Rape and Handed Over to Public Assistance during the Great War (1914-1918)", in Raphaelle BRANCHE and Fabrice VIRGILI (ed.), Rape in Wartime, New York, Palgrave Macmillan, 2012, p. 189-206.

18. MAHоOD Linda, "The Save the Children Fund and the Russian Famine of 1921-23: Claims and Counter-Claims about Feeding 'Bolshevik' Children", Journal of Historical 
Sociology, 22, 2009, p. 55-83, 56; see also BREEN Rodney, "Saving Enemy Children: Save the Children's Russian Relief Organisation, 1921-1923”, Disasters 18, 1994, p. 221-237.

19. VITTACHI Varindra Tarzie, Between the Guns: Children as a zone of peace, London, Hodder and Stoughton, 1993.

20. IRWIN Julia F., op. cit., p. 38.

21. KOVEN Seth, "Dr. Bernardos Artistic Fictions: Photography, Sexuality, and the Ragged Child", in Seth Koven, Slumming. Sexual and Social Politics in Victorian London, Princeton, Princeton University Press, 2004, p. 88-138; GODBY, Michael "Confronting Horror: Emily Hobhouse and the Concentration Camp Photographs of the South African War", in Kronos: Southern African Histories, 1, 2006, p. 34-48.

22. BURMAN Erica, "Innocents Abroad: Western Fantasies of Childhood and the Iconography of Emergencies", in Disasters. The Journal of Disaster Studies and Management, 18 (3), 1993, p. 238.

23. HALTTUNEN Karen, "Humanitarianism and the pornography of pain in Anglo-American culture", in American Historical Review 100, 1995, p. 307, 318.

24. MAHOOD Linda, "The Save the Children Fund and the Russian Famine of 1921-23: Claims and Counter-Claims about Feeding 'Bolshevik' Children”, Journal of Historical Sociology, 22, 2009, p. 57.

25. SONTAG Susan, "Looking at war", in The New Yorker, 2002/12/09, p. 86.

26. ASHBY WILSON Richard and BROWN, Richard D. eds., Humanitarianism and Suffering: The Mobilization of Empathy, New York, Cambridge University Press, 2009.

27. SLIM Hugo, "Relief agencies and moral standing in war: Principles of humanity, neutrality, impartiality and solidarity", in Development in Practice, 7 (4), p. 343.

28. VERNON James, Hunger. A Modern History, Cambridge, MA, London, UK, Harvard University Press 2007, p. 17, 19.

29. AUDOIN-ROUZEAU, BECKER, SMITH, op. cit., p. 227.

30. HEALEY Maureen, "Mobilizing Austria's Children for the War", in HEALEY, Vienna and the Fall of the Habsburg Empire, Cambridge, Cambridge University Press, 2004, p. 255.

31. HUBINETTE Tobias, "From Orphan Trains to Babylifts: Colonial Trafficking, Empire Building, and Social Engineering", in TRENKA Jane Jeong, OPARAH Julia Chinyere and SUDBURY Julia (ed.), Outsiders Within: Writing on Transracial Adoption, Cambridge MA, South End Press, 2006, p. 141.

32. O'GALLAGHER Marianna, "Children of the Famine", Beaver, 88, 2008, p. 50-56; MCCAUGHLIN Trevor, "Lost Children? Irish Famine Orphans in Australia", History Ireland, 8, 2000, p. 30-34.

33. RESSLER Everett M., воOTHBy, Neil and STEINBock Daniel J., Unaccompanied Children: Care and Protection in Wars, Natural Disasters, and Refugee Movements, Oxford, Oxford University Press, 1988; see also “Armenian Children's Victims of Genocide” the online exhibition on children of the Armenian genocide: [http://www.genocide-museum.am/eng/ online_exhibition_3.php] (accessed on March 25 2013); HOFMANN Tessa and KOUTCHARIAN Gerayer, "Images that Horrify and Indict: Pictorial Documents on the Persecution and Extermination of Armenians from 1877 to 1922", Armenian Review, 45, 1992, p. 177-178; ÜNGÖR Ugur Ümit ,"Orphans, Converts, and Prostitutes. Social Consequences of War and Persecution in the Ottoman Empire, 1913-1923", in War in History 18, 2012, p. 175-180. 
34. SMIRNOvA Tatiana M., "The Outcomes for Soviet Children Evacuated to Czechoslovakia in the Early 1920s", in Russian Studies in History, 48, 2010, p. 26-50; SMIRNOVA Tatiana M., "Beloved Children of the Soviet Republic", Russian Studies in History, 48, 2010, p. 9-25.

35. DANFORTH, Loring M., VAN BOESCHOTEN Riki, Children of the Greek Civil War. Refugees and the politics of memory. Chicago and London, The University of Chicago Press, 2012, p. 27.

36. See on this chapter 9: “'A Perfect Jungle of Intrigues, Suspicion and Hyprocrisies': The Early Save the Children Fund in Time of Crisis" (166-184) and chapter 10: "'Internationalization' of Charity in Peacetime: Declaring the Rights of the Child" (185-205), in Linda MAHOOD, Feminism and Voluntary Action: Eglantyne Jebb and Save the Children, Basingstoke, Palgrave Macmillan, 2009.

37. "History the Early Years" of Save the Children. [http://www.savethechildren.org.au/ about-us/history/history-the-early-years] (accessed on April 8 2013).

38. RAPPAPORT Helen, "Eglantyne Jebb", in Encyclopedia of Women Reformers, vol. I, Santa Barbara, ABC-Clio, 2001, p. 333.

39. TÁBORI Kornél, Egy halálraitélt ország borzalmaiból [From the Horrors of the War], Budapest, Kultura, 1920, p. 1.

40. Translation from German by the author. Letter by the Niederösterreichische Landesberufungsvormundschaft, Hauptstelle Wien, to the K.u.K. Ministry of Social Welfare, Vienna 1918/02/25. Österreichisches Staatsarchiv/Archiv der Republik (ÖStA/ AdR), Bundesministerium für soziale Verwaltung (BMfsV), Jugendfürsorge, 1918, 6477.

41. VInCENT C. Paul, The Politics of Hunger: Allied Blockade of Germany, 1915-1919, Ohio, Ohio University Press, 1985.

42. cox Mary Elisabeth, "War, Blocakdes, and Hunger: Nutritional Deprivation of German Children 1914-1924", in Discussion Papers in Economic and Social History, 110, 2013, p. 1-36. [http://www.economics.ox.ac.uk/materials/papers/12623/Cox\%20110.pdf] (accessed on April 4th 2013), 1.

43. "History" of Save the Children, op. cit.

44. DEN HERTOG Johan, "The commission for Relief in Belgium and the Political Diplomatic History of the First World War", Diplomacy and Statecraft, 21, 2010, p. 593-613.

45. KRAMER Alan, Dynamic of Destruction. Culture and Mass Killing in the First World War, Oxford, Oxford University Press, 2007, p. 155.

46. HERWIG Holger H., The First World War: Germany and Austria-Hungary, 1914-1918, London, Arnold, 1997, p. 271-283.

47. HEGEDÜS Judit, "Kleinkinderpflege- und Kinderschutzbewegung während der k.u.k. Monarchie", in Johanna HOPFNER and András NÉMETH (ed.), Pädagogische und kulturelle Strömungen in der k.u.k. Monarchie. Lebensreform, Herbartianismus und reformpädagogische Bewegungen, Frankfurt am Main, Peter Lang Verlag, 2008, p. 185.

48. SONTAG Susan, op. cit., p. 42-43.

49. Translation from German by the author. Letter by the k.k. Amt für Volksernährung to the k.k Ministerium für soziale Fürsorge, 1918/01/16, Sozialfürsorge 1918, Österreichisches Staatsarchiv/Archiv der Republik (ÖStA/AdR), Bundesministerium für soziale Verwaltung (BMfsV), Jugendfürsorge, 1918.

50. HÄMMERLE Christa, Kindheit im Ersten Weltkrieg, Wien-Köln-Weimar, Böhlau, 1993, p. 333. 
51. Translation from German by the author. Expositur des k.ung. Regierungskommissar für das unter aller höchster Schirmherrschaft stehende König-Karl Wohlfahrtswerk "Kinder aufs Land" an den löblichen Gemeindevorstand, 1918/07/01, Državni Arhiv u Rijeci [Staatsarchiv Rijeka], HR-DARI-29 (Glavarstvo općine Volosko-Opatija), Opći spis $1588 / 18$.

52. «Sorozzák a gyermekeket» [Recruiting the Children], Vajda Manó felvételel, in $A z$ Érdekes Újság. VI Évfolyam, 24 sz. Junius 13, 1918, p. 32.

53. Pesti Hirlap, "Ungarische Blätter über die Kinderaktion", "Kaiser Karl Wohlfahrtswerk Der König für die Kinder”, Wien, HHStA Kabinettsarchiv Korrespondenzakten 1918, 291.

54. Translation from German by author. Leaflet of the Kaiser Karl Wohlfahrtswerk "Kinder aufs Land", K.u.K. Ministerium für soziale Fürsorge, Österreichisches Staatsarchiv/Archiv der Republik (ÖStA/AdR), Bundesministerium für soziale Verwaltung (BMfsV), Jugendfürsorge, 1918.

55. Report by Hugo WAGNER, K.u.K. Prof. Gyula, 1918/08/16, K.u.K. Ministerium für soziale Fürsorge, Österreichisches Staatsarchiv/Archiv der Republik (ÖStA/AdR), Bundesministerium für soziale Verwaltung (BMfsV), Jugendfürsorge, 1918.

56. Ibid.

57. FISCHER Vladimir, Waltraud HEINDL, and Alexandra MILLNER (ed.), Räume und Grenzen in Österreich-Ungarn, 1867-1918. Kulturwissenschaftliche Annäherungen, Basel, Francke, 2010; FINK Maria, Die Österreichisch-Ungarische Monarchie als Wirtschaftsgemeinschaft, München, Trofenik, 1968.

58. Report by WAGNER, op. cit.

59. Report by WAGNER, op. cit.

60. Translation from German by author. K.u.K. Ministerium des kaiserlichen und königlichen Hauses und des Äussern, "Wiener Kinder in der Schweiz", Wien, 1918/01/07. Österreichisches Staatsarchiv/Archiv der Republik (ÖStA/AdR), Bundesministerium für soziale Verwaltung (BMfsV), Jugendfürsorge, 1918, 903.

61. Ibid.

62. Ibid.

63. In Hungary it became known as the Károly Király Gyermeknyaraltatása.

64. PETTKO-SZANDTNER Aladár, A Huszonötéves àllami Gyermekvédelem Emlékkönyve, Budapest, A. M. kir. népjóléti és munkaügyi Miniszterium, 1928, p. 304.

65. Translation from German by author. Pester Llyod, 1918/03/31, Kabinettsarchiv Korrespondenzakten 1918:291, Haus Hof und Staatsarchiv, Vienna, Austria.

66. Translation from German by author. "Der König und die armen Kinder", in Deli Hirlap, Kabinettsarchiv Korrespondenzakten 1918, 291, Haus Hof und Staatsarchiv, Vienna, Austria.

67. Translation from German by author. Leaflet of the Kaiser Karl Wohlfahrtswerk, "Kinder...", ibid.

68. Károly király gyermeknyaraltatása. Indulás a Keleti pályaudvarra, 1918. Müllner János felvétele, Reference: 12862.116. Budapest History Museum, Museum Kiscell Picture Collection.

69. Károly király gyermeknyaraltatása. Beszállás a vonatra. 1918. Müllner János felvétele, Reference: 13862.112. Budapest History Museum, Museum Kiscell Picture Collection. 
70. Károly király gyermeknyaraltatása.A vonaton. 1918. Müllner János felvétele, Reference: 13862.111. Budapest History Museum, Museum Kiscell Picture Collection.

71. "Österreichische Kinder auf kostenlosem Urlaub in Ungarn", Magyarorszag nyaralásra induló ausztrák gyerekek vonatja induló elött a bécsi palyaudvaron. 1918. Reference: 61.654. Historical Photo Gallery, Hungarian National Museum Budapest.

72. BARONA VILAR Josep L., "International organisations and the development of a physiology of nutrition during the 1930s", in Food \& History, 6, 2008, p. 130.

73. TREITEL Corinna, "Max Rubner and the Biopolitics of Rational Nutrition," in Central European History, 41, 2008, p. 11.

74. WEINDLING Paul, "From Sentiment to Science - Childrens Relief Organizations and the Problem of Malnutrition in Interwar Europe2, in Disasters, 18, 1994, p. 203-212, p. 204.

75. Translation from German by author. Leaflet of the Kaiser Karl Wohlfahrtswerk, "Kinder...", op. cit..

76. Idem.

77. Idem.

78. Károly Kiraly Gyermeknyaraltatási akció. [Kaiser Karl Holiday Action], "Needy Hungarian Children in Austria. Sunbathing. 1918. Reference: 61.646. Historical Photo Gallery, Hungarian National Museum Budapest.

79. Austriaban nyaraló Magyar gyerekek. Reggeli toilette. Reference 61.651. Historical Photo Gallery, Hungarian National Museum Budapest.

80. Abbáziában nyaraló Magyar gyerekek. Visszatérés egy vitorlásútról. 1918. Reference 61.644. Historical Photo Gallery, Hungarian National Museum Budapest.

81. Translation from Hungarian by author. PETTKO-SZANDTNER, A Huszonötéves..., p. 306.

82. Translation from German by author. Leaflet of the Kaiser Karl Wohlfahrtswerk, "Kinder...", op. cit..

83. Translation from Hungarian by the author. "Magyar gyerekek nyaraltatása", in Pesti Hirlap, XI. évfolyam, 180 szám, 04/08/1918, p. 1.

84. Translation from Hungarian by the author. VADNAY Tibor, "Károly Király Gyermeknyaraltatása", in Béla KÁDÁR and Vilmos SARBó, (ed.), A Nagy Vihar Hajótöröttei, Budapest, Wodianer, 1927, p. 147-171, p. 160.

85. „A királyi pár a gyerkek között“, in Az Érdekes Ujság, VI évfolyam 49, Oktober 19 1918, p. 38.

86. Translation from German by author. Leaflet of the Kaiser Karl Wohlfahrtswerk, "Kinder...", op. cit.

87. Translation from German by the author. K.K Ministerium für soziale Fürsorge, "Unterbringung österreichischer Kinder", 1918/08/28. Österreichisches Staatsarchiv/ Archiv der Republik (ÖStA/AdR), Bundesministerium für soziale Verwaltung (BMfsV), Jugendfürsorge, 1918, 21959.

88. HEALEY Maureen, “Mobilizing...” p. 213.

89. Translation from Hungarian by the author. VADNAY, Károly Király..., p. 154.

90. Ibid. 
91. American Relief Administration European Children's Fund, Final Report of the Work in Hungary written by the Members of the American Child Welfare Mission, Budapest, 1920/06/01, p. 1.

92. Letter by Dr. John Szekeres to the Save the Children Fund, "A crisis in intellectual and physical work in Hungary", Budapest, 1921/10/27, Eglantyne Jebb Papers Hungary, A 0407, EJ 149-166, Save the Children Fund Archive, Cadbury Research Library, Special Collections, University of Birmingham.

93. CHANEBY William L., "Starving Budapest: Capital of Human Misery", in The New York Times, 1920/05/30.

94. LIBER Andrew, "Account on circumstances of subsistence in Budapest. How is life in Budapest?", Budapest, 1921/10/21, 34 pages, p. 29-30, Eglantyne Jebb Papers Hungary, A 0407, EJ 149-166, EJ 155 Hungary, Folder $n^{\circ} 2$, 1920-21, International Commissioners Reports and Correspondence, Save the Children Fund Archive, Cadbury Research Library, Special Collections, University of Birmingham.

95. BRUBAKER Rogers, "Aftermaths of Empire and the Unmixing of Peoples provides a very inspiring analysis of the interconnection between the end of empires and migration", in Karen BARKEY and Mark VON HAGEN (ed.), After empire. Multiethnic Societies and NationBuilding. The Soviet Union and the Russian, Ottoman, and Habsburg Empires, Boulder, Colorado, West View Press, 1997, p. 160.

96. Translation from Hungarian by author. LIBER, “Account on circumstances...” p. 2.

97. Translation from Hungarian by author. TÁBORI, Egy halálraitélt..., p. 1.

98. Ibid.

99. Ibid.

100. BURMAN Erica, op. cit; p. 239.

101. CHERNA Andrew, "Report to the American Red Cross on Investigation in Austria and Hungary", 1923/09, p. 5, Records of the American National Red Cross 1917-1934, 953.08, Hungary, Budapest Unit WWI, Reports, Statistics, Surveys and Studies, National Archives at College Park, Washington.

102. Translation from French by the author. "Union Internationale de Secours aux enfants. Extract from Report of Bunier. Delegate of C.I.C.R.", 1920/10, p.1-2, p.2, Eglantyne Jebb Papers Hungary, A 0407, EJ 149-166, EJ 155 Hungary, Folder No. 2, 1920-21, International Commissioners Reports and Correspondence, Save the Children Fund Archive, Cadbury Research Library, Special Collections, University of Birmingham.

103. ROTTENBILLER Fülöp, Az Országos Gyermekvédö Liga harminc évi müködése 1906-1936, (Thirty years work of the National League for Child Protection), Budapest, Fővárosi Nyomda Részvénytársaság,1936, p. 23.

104. Letter by J. E. Vajkai to Elgantine Jebb, 1920/15/05 (most probably 1920), Eglantyne Jebb Papers Hungary, A 0407, EJ 149-166, EJ 151 Hungary, Save the Children Fund Archive, Cadbury Research Library, Special Collections, University of Birmingham.

105. Ibid.

106. GOLDEN L. B., "Report to the Council of the S.C.F. and the Executive Committee of the UISE on the SCF and UISE Work in Central Europe and the Balkans", Geneva, 1926/03, 14 pages, p. 3. Eglantyne Jebb Papers Hungary, A 0407, EJ 149-166, EJ 166 Hungary, Folder ${ }^{\circ}$ 
2, 1920-21, International Commissioners Reports and Correspondence, Save the Children Fund Archive, Cadbury Research Library, Special Collections, University of Birmingham.

107. Hoover and the ARA equally aimed at establishing long-lasting local structures, which could after the end of the war or any other type of distressing situation be continued without further personal help of the ARA.

108. Translation from Hungarian by author. TÁBORI Kornél, Egy halálraitélt..., last cover page.

109. Mademoiselle Ferrieré's Report, 1920/09/24, Eglantyne Jebb Papers Hungary, A 0407, EJ 149-166, EJ 155 Hungary, Folder $n^{\circ} 2$, 1920-21, International Commissioners Reports and Correspondence, Save the Children Fund Archive, Cadbury Research Library, Special Collections, University of Birmingham.

110. Letter to Save the Children Fund, Christmas 1922, Eglantyne Jebb Papers Hungary, A 0407, EJ 149-166, Save the Children Fund Archive, Cadbury Research Library, Special Collections, University of Birmingham.

111. HAJTó Vera, “The 'wanted' children. Experiences of Hungarian children in Belgian foster families during the interwar period", in History of the Family, 14, 2009, p. 206; see also FERENC Gergely, A Magyar Gyermekvédelem Története, Budapest, Püski, 1997, p. 32.

112. ROTTENBILLER Fülöp, Az Országos Gyermekvédő Liga harminc évi müködése 1906-1936, (Thirty years work of the National League for Child Protection), Budapest, Fővárosi Nyomda Részvénytársaság, 1936, p. 25, 27.

113. „Hatszáz Magyar gyermek hazaérkezése Hollandiából. [Six hundred Hungarian children arrive back from Holland]”, in Érdekes Ujság, 1921, IX Èvfolyam, 39 Szám, p. 4.

114. Translation from Hungarian by the author, "Nyilatkozat", 1928/03/31, Magyar Országos Levéltár, K 319-19-1941-23, Csomag 4.

115. "A külföld a Magyar gyermekért", [Foreign countries for Hungarian Children], in Új idök, xxvi Évfolyam, 11 szám, 1920/04/24, p. 27.

116. MÜHLBECK Károly, “Foreign countries for Hungarian Children”, in Új Idök, 11 (1920).

117. See for this the inspiring work of HAJTó Vera on the child transports to Belgium. HAJTó Vera, op. cit.

118. Translation from Hungarian by the author. Letter by the Magyar Kir. Titkos Tanácsos Üv. Elnök to the Elüljárósághoz Szalkkszentmárton, Budapest, 1938/11/21, Magyar Országos Levéltár, K 319-19-1941-23, Csomag 4.

119. Ibid.

120. NEVINSON Henry W., "The Black Outlook in Europe", in The Manchester Guardian, 1920/03/08, p. 14.

121. Translation from Hungarian by the author. KRÚDY Gyula, Liga Gida Kalandjai. Hollandiában És a Világ Egyéb Tájain, Budapest, Országos Gyermekvédő Liga, 1923, p. 3.

122. Translation from Hungarian by the author. „A magyar gyermek-a nagyvilágban“, in Csálad és gyermek 1. Évf. 5-6 Szám, September 1928, p. 3-6, p. 4.

123. Ibid., p.5.

124. Translation from German by the author. Gesellschaft Helvetica-Hungaria, "Vergangenheit", [http://www.helvetia-hungaria-nw.ch/de/index.php?menu2=66] [last accessed 2012/07/26]. 
125. Translation from German by the author. Zentralstelle der schweizerischen Hilfsaktion für ungarische Kinder, Baden, Schweiz, 1921/10/14, addressed to the International Save the Children Fund in Geneva. Eglantyne Jebb Papers Hungary, A 0407, EJ 149-166, Save the Children Fund Archive, Cadbury Research Library, Special Collections, University of Birmingham.

126. Letter by Mr. Bohlen to Lord Wardale from 1920/12/20, Eglantyne Jebb Papers Hungary, A 0407, EJ 149-166, Save the Children Fund Archive, Cadbury Research Library, Special Collections, University of Birmingham.

127. Letter by the Allocations Department to Julia Vajkai from 1922/03/01, Eglantyne Jebb Papers Hungary, A 0407, EJ 149-166, Save the Children Fund Archive, Cadbury Research Library, Special Collections, University of Birmingham.

128. “Child's Protection League: Question-sheet for the Children's [After Care] Hospitality Committee”, 1922, Eglantyne Jebb Papers Hungary, A 0407, EJ 149-166, EJ 151 Hungary, Save the Children Fund Archive, Cadbury Research Library, Special Collections, University of Birmingham.

129. Translation from Hungarian by the author. PETTKO-SZANDTNER Aladár, A Huszonötéves..., p. 312.

130. мӥньвеск Károly: "Itt a hollandi papák és mamák", [Here are the Dutch Fathers and Mothers], in Uj Idök, xxx Évfolyam, 29 szám, 1924/06/01, p. 435.

131. Translation from Hungarian by the author. "Katta Hollandiaban elfelejtett valamit", in Uj Idök, XXX Évfolyam, 29 Szám, July 13 1924, p. 52-53.

132. Idem, p. 53.

133. Idem, p. 53.

134. SONTAG Susan, ibid., p. 19.

135. KENNEDY Dennis, "Selling the Distant Other. Humanitarianism and Imagery-Ethical Dilemmas of Humanitarian Action", in The Journal of Humanitarian Assistance, 2009/02/28, [http://sites.tufts.edu/jha/archives/411] [last accessed 2012/08/04].

\section{ABSTRACTS}

Much has been written and told about the child transports, the well-known Kindertransporte, related to the Nazi period and World War II. Yet, astonishingly little is known about the child transports related to Europe's First World War. This article is aiming to fill this research gap on the historical landscape, telling the history of child transports during and after WWI from and across Central Europe. These child transports were originally meant to provide short-term relief, but they sometimes even resulted in children's long-term placement abroad. The organizations' and birth families' primary interest in the child transports was to improve children's physical well-being, ignoring their subjectivity to a great extent. The physical appearance of a child's body, namely its underweight, sickness, or malnutrition was conditional for the participation in the child transports of the time. Visual imagery, including drawings, photography posters and everyday objects, were essential to justify, illustrate, and document children's suffering and their 
geographic displacement. Paying special attention to the visual dimension of this particular relief activity, this article will uncover the transformation of early twentieth century child transports from the late Austro-Hungarian Empire to Europe's humanitarian-internationalist post-WWI era.

On a beaucoup écrit sur les transports d'enfants, les fameux « Kindertransport " associés à la période nazie et à la seconde guerre mondiale. Pourtant, on sait peu de choses des déplacements d'enfants durant la première guerre mondiale. Cet article entend combler ce vide historiographique, en faisant l'histoire de ces migrations juvéniles pendant et après la guerre, en Europe centrale. Ce type de migration était originellement prévu pour offrir une aide temporaire, mais il a parfois résulté dans le placement de longue durée à l'étranger. L'objectif premier des associations et des familles était d'améliorer le bien-être physique des enfants, en ignorant largement leur ressenti. L'apparence physique d'un corps d'enfant, la maladie ou la malnutrition était une condition pour être admis au départ. L'iconographie, incluant les dessins, les affiches photographiques et les objets du quotidien, étaient essentiels pour justifier, illustrer et documenter la souffrance enfantine et leur exode. En prêtant une attention particulière aux sources graphiques de cette activité caritative, cet article entend dévoiler le passage des pratiques austro-hongroises de déplacement d'enfants du début du siècle à l'aide humanitaire internationale des lendemains de guerre.

\section{INDEX}

Mots-clés: déplacements d'enfants, première guerre mondiale, empire austro-hongrois, iconographie

Keywords: child displacement, World War I, Austro-Hungarian Empire, iconography

\section{AUTHOR}

\section{FRIEDERIKE KIND-KOVÁCS}

Friederike Kind-Kovács is Assistant Professor at the Department of Southeast- and East European History at Regensburg University. She graduated from St. Andrews University in Modern History and completed her Ph.D. at Potsdam University in 2008. Recently she has co-edited a volume: Samizdat, Tamizdat, and beyond. Transnational media during and after socialism, New York, Berghahn, 2013. 